Acta Botanica Brasilica - 31(3): 503-524. July-September 2017.

doi: 10.1590/0102-33062017abb0088

Review

\title{
Elaiophores: their taxonomic distribution, morphology and functions
}

\author{
Clivia Carolina Fiorilo Possobom ${ }^{1}$ and Silvia Rodrigues Machado ${ }^{2 \star}$
}

Received: March 10, 2017

Accepted: March 23, 2017

\begin{abstract}
Elaiophores are floral glands that secrete non-volatile oils as a reward for their pollinators. Their secretions mediate a specialized interaction between oil-producing plants and a few species of oil-collecting bees - Apidae and Melittidae. The present review focuses on the morphological and functional aspects of these secretory structures. We also provide information on their chemistry and pollination ecology. Our survey is organized taxonomically among the plant families for which elaiophore occurrence has been confirmed -for the monocots, Iridaceae and Orchidaceae, and for the eudicots, Calceolariaceae, Cucurbitaceae, Krameriaceae, Malpighiaceae, Plantaginaceae, Primulaceae, Scrophulariaceae, Solanaceae and Stilbaceae. Most oil flowers are zygomorphic, bisexual, nectarless and present their elaiophores on the protective whorls or on the androecium. Trichomal elaiophores are reported in all of these families except Krameriaceae and Malpighiaceae, and they vary in the density and morphology of the trichomes. Epithelial elaiophores occur in some monocot representatives and in Krameriaceae and Malpighiaceae, and are similar among species. An intermediate type of elaiophore is reported in some species of Orchidaceae. Regardless of elaiophore type, these glands have similar subcellular features and secretion-release mechanisms. Finally, we note the dearth of information on elaiophore ultrastructure and functioning for several plant families.
\end{abstract}

Keywords: Asparagales, bees, Cucurbitales, Ericales, Lamiales, Malpighiales, oil flowers, Solanales, Zygophyllales

\section{Introduction}

Elaiophores are a type of floral secretory structure whose secretions act as the primary attractant in a mutual relationship between oil-producing flowers and oil-collecting bees -thus their potential pollinators.

This specialized pollination system was first reported in Angelonia and Calceolaria species by Vogel (1969; 1971; 1974). His discovery opened up a new area of research that has since been explored by many authors. In addition to Vogel's early publications and those of others presented here, general and more recent information on oil-producing flowers and/or on oil-collecting bees can be found in Simpson \& Neff (1981), Buchmann (1987), Rasmussen \& Olesen (2000), Machado (2004), Alves-dos-Santos et al. (2007) and Renner \& Schaefer (2010).

In his first full publication (1974) on the subject Ölblumen und ölsammelnde Bienen (Oil flowers and oil collecting

\footnotetext{
${ }^{1}$ Instituto de Ciências Agrárias, Universidade Federal de Minas Gerais, 39404-547, Montes Claros, MG, Brazil

${ }^{2}$ Departamento de Botânica, Instituto de Biociências de Botucatu, Universidade Estadual Paulista, 18618-970, Botucatu, SP, Brazil

* Corresponding author: smachado@ibb.unesp.br
} 
bees) Vogel provided information on the morphology, chemical nature of secretions and ecological functions of elaiophores in some species of the Iridaceae, Krameriaceae, Malpighiaceae, Orchidaceae and Scrophulariaceae. Some Scrophulariaceae species are now included in the Calceolariaceae, Plantaginaceae and Stilbaceae (sensu APG IV 2016). Since then, other families have been added to the list including the Cucurbitaceae (Vogel 1976b apud Simpson \& Neff 1981), Fabaceae (Vogel 1988), Gesneriaceae (Steiner 1985b), Melastomataceae (Buchmann \& Buchmann 1981), Primulaceae (Vogel 1976a) and Solanaceae (Simpson \& Neff 1981). These now total 14 families with known or suspected oil-producing species (see Tab. 1). For the Fabaceae, Gesneriaceae and Melastomataceae there is not yet sufficient evidence to confirm that the oil-producing structures are actually true elaiophores (sensu Vogel), so they are not included in the list of plant families that offer oil as a reward to their pollinators.

The wide distribution of the elaiophores among unrelated families of monocots and eudicots (Tabs. 1, 2) indicates a polyphyletic evolution for this character (Vogel 1974; Buchmann 1987; Renner \& Schaefer 2010). According to Renner \& Schaefer (2010) oil flowers evolved at least 28 times after the K-T boundary and they have also been lost 36-40 times.

According to Vogel (1974) the oil can be produced by elaiophores constituted by a set of secretory trichomes or by a secretory epithelium recovered by a single cuticle under which the secretion is stored.

In general, elaiophore secretions consist mainly of fatty acids and/or glycerides (see Vogel 1974; Simpson et al. 1977; Seigler et al. 1978; Simpson et al. 1979; Simpson \& Neff 1981; Buchmann 1987; Cocucci 1991; Vinson et al. 1997; Reis et al. 2000; Reis et al. 2003; Seipold et al. 2004; Reis et al. 2006; Reis et al. 2007; Dumri et al. 2008; Vogel 2009). However, other constituents have also been reported as minor constituents including: aldehydes, amino acids, carbohydrates, carotenoids, hydrocarbons, isoprenoid compounds, ketones, phenolic compounds, saponins, and terpenes (see Vogel 1974; Simpson \& Neff 1981; Cane et al. 1983; Buchmann 1987; Lobreau-Callen 1989; Reis et al. 2006).

The floral oil is gathered by female solitary bees belonging to a number of genera of the Melittidae (Melittinae subfamily) and Apidae (Centridini, Ctenoplectrini, Tapinotaspidini and Tetrapediini tribes) (sensu Michener 2007; Tab. 1). The abdomen (Ctenoplectrini bees) or the front and/or middle legs of these bees generally have specialized oil-collecting structures, such as pads or combs of branched or simple setae (see Vogel 1974; Neff \& Simpson 1981; Cocucci et al. 2000; Machado 2004; Alves-dos-Santos et al. 2007; Michener 2007). According to Vogel (1974) and Neff \& Simpson (1981) the features of the oil-collecting organs can be correlated with the type of elaiophore (i.e. epithelial or trichomal). That is, bees that visit trichomal elaiophores generally have pads of setae, while bees visiting epithelial elaiophores have brush-like combs of modified setae or combs of spatulate setae.

The bees use the oil, sometimes mixed with pollen, for larval food provisioning (see Vogel 1974; Simpson et al.1977; Vinson et al.1996; Vinson et al.1997; Alves-dos-Santos et al. 2002; Michener 2007; Reis et al. 2007; Vogel 2009; Schäffler \& Dötterl 2011); for nest waterproofing (see Neff \& Simpson 1981; Simpson \& Neff 1981; Cane et al.1983; Buchmann 1987; Alves-dos-Santos et al. 2002; Michener 2007; Vogel 2009; Schäffler \& Dötterl 2011) or for nest construction (see Vinson et al. 1996; Alves-dos-Santos et al. 2002). Since the oil flowers are generally without nectar and considering that there is no clear evidence the adult bees consume the floral oil, the bees are also likely to be dependent on nectar from other flowers (Michener 2007).

After more than 40 years since the discovery of this specialized pollination system, information on the distribution of elaiophores among the angiosperms remains imprecise and incomplete. This compilation focuses mainly on the taxonomic distribution and the morphological features of elaiophores but also provides information on oil chemistry and pollination ecology. Our intent is to contribute to a better understanding of the distribution, diversity and functional aspects of elaiophores among angiosperms, with the hope of stimulating new study in this interesting field. Our findings are organized on the basis of the plant taxonomic groups in which elaiophores are known to occur.

\section{Asparagales}

\section{Iridaceae}

Iridaceae is an almost cosmopolitan family of some 2115 species in 66 genera (Stevens 2001). This family is particularly diverse in Africa and shows considerable floral diversification and a wide range of pollination syndromes (Rudall et al. 2003; Goldblatt \& Manning 2006). The flowers offer pollen, nectar and sometimes oil for the pollinators, which include bees, beetles, flies, butterflies, moths and birds (Rudall et al. 2003; Goldblatt \& Manning 2006).

Oil-secreting trichomes are recorded on several New World genera of the Sisyrinchieae, Tigridieae and Trimezieae (Iridoideae) (Rudall et al. 2003; Chaveau et al. 2012; see Tab.1). According to Chaveau et al. (2012) the trichomal elaiophores have evolved independently multiple times in the tribes of Iridoideae, corroborating the findings of Renner \& Schaefer (2010).

The trichomes can be concentrated on the base of the staminal column, on the base of the inner surface of the tepals or along the middle vein of each tepal (Vogel 1974; Goldblatt et al.1998; Cocucci \& Vogel 2001; Chaveau et al. 2011; 2012; Silvério et al. 2012; see Tab.2). In the Sisyrinchieae, trichomes can occur on both the column 
Table 1. Taxa with known or suspected oil-producing flowers and their related oil-collecting bees.

\begin{tabular}{|c|c|c|c|c|c|c|c|}
\hline \multicolumn{5}{|c|}{ Taxonomic classification* } & $\begin{array}{l}\text { Taxa with oil-offering flowers in at least one } \\
\text { species (total of species in the genus)** }\end{array}$ & Genus of oil-collecting bees & References \\
\hline \multirow{12}{*}{ 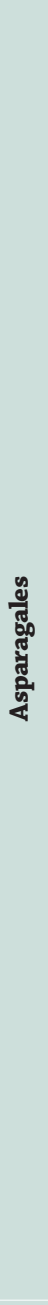 } & \multirow{4}{*}{ 苋 } & \multicolumn{3}{|c|}{ Crocoideae } & Tritoniopsis (20) & Rediviva & Manning \& Goldblatt 2002 \\
\hline & & \multirow{3}{*}{ 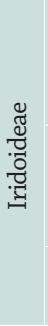 } & \multicolumn{2}{|r|}{ Sisyrinchieae } & Sisyrinchium (85) & Chalepogenus, Lanthanomelissa, Tapinotaspis & $\begin{array}{l}\text { Vogel 1974; Buchmann 1987; Goldblatt et al. } \\
\text { 1998; Cocucci \& Vogel 2001; Chaveau et al. 2011; } \\
\text { Chaveau et al. 2012; Silvério et al. } 2012\end{array}$ \\
\hline & & & & Tigridieae & $\begin{array}{l}\text { Alophia (5), Calydorea (8), Cardenanthus (8), } \\
\text { Cipura (6), Cypella (20), Ennealophus (5), } \\
\text { Herbertia (5), Kelissa (1), Mastigostyla (16), Onira } \\
\text { (1), Tigridia (30) }\end{array}$ & Centris, Chalepogenus, Paratetrapedia & $\begin{array}{l}\text { Vogel 1974; 1988; Buchmann 1987; Goldblatt et } \\
\text { al. 1998; Chaveau et al. 2011; Chaveau et al. } 2012\end{array}$ \\
\hline & & & & Trimezieae & Trimezia (20) & - & $\begin{array}{l}\text { Simpson \& Neff 1981; Buchmann 1987; } \\
\text { Chaveau et al. } 2012\end{array}$ \\
\hline & \multirow{8}{*}{ 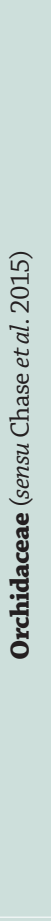 } & \multirow{3}{*}{ 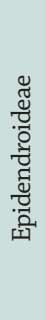 } & \multirow[b]{3}{*}{ 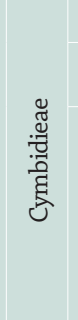 } & Catasetinae & Grobya (5) & Paratetrapedia & Mickeliunas et al. 2006; Pansarin et al. 2009 \\
\hline & & & & Maxillariinae & Rudolfiella (6) & - & Davies \& Stpiczyńska 2009 \\
\hline & & & & Oncidiinae & $\begin{array}{l}\text { Chytroglossa (3), Cyrtochilum (137), Gomesa } \\
\text { (119), Hintonella (1), Lockhartia (28), Oncidium } \\
\text { (311), Ornithocephalus (55), Phymatidium (10), } \\
\text { Platyrhiza (1), Trichocentrum (70), Vitekorchis (4), } \\
\text { Zygostates (22) }\end{array}$ & Centris, Lophopedia, Tetrapedia & $\begin{array}{l}\text { Vogel 1974; Singer \& Cocucci 1999; Alves-dos- } \\
\text { Santos et al. 2002; Reis et al. 2003; Reis et al. } \\
\text { 2006; Pacek \& Stpiczyńska 2007; Stpiczyńska } \\
\text { et al. 2007; Aliscioni et al. 2009; Pansarin \& } \\
\text { Pansarin 2011; Torretta et al. 2011; Neubig et al. } \\
\text { 2012; Pacek et al. 2012; Blanco et al. } 2013\end{array}$ \\
\hline & & \multirow{5}{*}{ 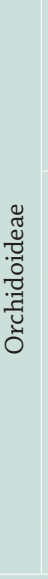 } & 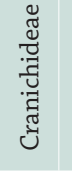 & Cranichidinae & Ponthieva (66) & - & Dressler 1993 apud Salazar et al. 2009 \\
\hline & & & \multirow{4}{*}{ 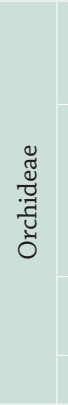 } & Brownleeinae & Disperis (78) & Rediviva & $\begin{array}{l}\text { Buchmann 1987; Manning \& Linder 1992; Pauw } \\
\text { 2006; Whitehead et al. 2008; Waterman et al. } \\
2009\end{array}$ \\
\hline & & & & Coryciinae & $\begin{array}{l}\text { Ceratandra (6), Corycium (15), Evotella (1), } \\
\text { Pterygodium (19) }\end{array}$ & Rediviva & $\begin{array}{l}\text { Buchmann 1987; Whitehead \& Steiner 1992; } \\
\text { 1993; Linder \& Kurzweil 1994; Steiner 1998; } \\
\text { Pauw 2006; Waterman et al. 2009; Steiner et } \\
\text { al. } 2011\end{array}$ \\
\hline & & & & Disinae & Huttonaea (5) & Rediviva & $\begin{array}{l}\text { Buchmann 1987; Whitehead et al. 2008; } \\
\text { Steiner } 2010\end{array}$ \\
\hline & & & & Orchidinae & Satyrium (86) & - & Buchmann 1987 \\
\hline 怤 & 迆 & \multicolumn{3}{|c|}{$\begin{array}{c}\text { Cucurbitoideae } \\
\text { Joliffieae grade } \\
\text { (sensu Kocyan et al. 2007) }\end{array}$} & $\begin{array}{l}\text { Baijiania (1), Indofevillea (2), Momordica (47), } \\
\text { Siraitia (4), Telfairia (3), Thladiantha (25) }\end{array}$ & Ctenoplectra & $\begin{array}{l}\text { Vogel 1981; 1988; Schaefer \& Renner 2008; } \\
\text { 2011; Sung et al. 2009; Renner \& Schaefer 2010; } \\
\text { Schaefer et al. } 2012\end{array}$ \\
\hline
\end{tabular}


Clivia Carolina Fiorilo Possobom and Silvia Rodrigues Machado

Table 1. Cont.

\begin{tabular}{|c|c|c|c|c|c|}
\hline \multicolumn{3}{|c|}{ Taxonomic classification* } & $\begin{array}{l}\text { Taxa with oil-offering flowers in at least one } \\
\text { species (total of species in the genus)** }\end{array}$ & Genus of oil-collecting bees & References \\
\hline 氙 & 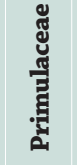 & Myrsinoideae & Lysimachia (180) & Macropis & $\begin{array}{l}\text { Vogel 1976a; 1986; 1988; Simpson et al.1983; } \\
\text { Cane et al.1983; Anderberg et al. 2007; Dötterl } \\
\text { \& Schäffler 2007; Schäffler \& Dötterl 2011; } \\
\text { Schäffler et al. } 2012\end{array}$ \\
\hline 茇 & 苋 & Caesalpinioideae & $\begin{array}{l}\text { Caesalpinia spp.*** } \\
\text { Hoffmannseggia spp.*** }\end{array}$ & Centris ??? & Vogel 1988 \\
\hline \multirow{6}{*}{ 苞 } & & Calceolariaceae & Calceolaria (245) & Centris, Chalepogenus, Tapinotaspis & $\begin{array}{l}\text { Vogel 1974; 1988; Molau 1988; Rasmussen \& } \\
\text { Olesen 2000; Sérsic 2004; Cosacov et al. 2012; } \\
\text { Cosacov et al. 2014; Murúa et al. } 2014\end{array}$ \\
\hline & & Gesneriaceae & Drymoniaserrulata*** & - & Steiner $1985 b$ \\
\hline & 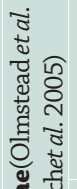 & Angelonieae & $\begin{array}{l}\text { Angelonia (26), Basistemon (8), Monopera (2), } \\
\text { Monttea (3) }\end{array}$ & $\begin{array}{l}\text { Arhysoceble, Caenomanda, Centris, Chalepogenus, } \\
\text { Lophopedia, Paratetrapedia, Tapinotaspis, } \\
\text { Tetrapedia }\end{array}$ & $\begin{array}{l}\text { Vogel 1974; 1988; Simpson et al. 1990; Vogel \& } \\
\text { Machado 1991; Sérsic \& Cocucci 1999; Machado } \\
\text { et al. 2002; Aguiar \& Melo 2009; Tadey 2011; } \\
\text { Martins \& Alves-dos-Santos 2013; Martins et al. } \\
\text { 2013; Martins et al. 2014; Ferreiro et al. } 2015\end{array}$ \\
\hline & हึ & Gratioleae & Mecardonia (10) & Chalepogenus & Cappellariet al. 2009 \\
\hline & 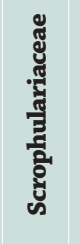 & Hemimerideae & $\begin{array}{l}\text { Alonsoa (11), Colpias (1), Diascia (50), Hemimeris } \\
\text { (4) }\end{array}$ & Rediviva & $\begin{array}{l}\text { Vogel 1974; 1984; Steiner 1989; 1990; 1996; } \\
\text { 1999; 2009; Simpson et al. 1990; Steiner \& } \\
\text { Whitehead 1990; 1991; 2002; Whitehead \& } \\
\text { Steiner 1992; Kampny 1995; Olmstead et al. } \\
\text { 2001; Fischer 2004; Pauw 2005; Dumri et al. } \\
\text { 2008; Whitehead et al. 2008; Kuhlmann \& } \\
\text { Hollens } 2015\end{array}$ \\
\hline & 苋 & $\begin{array}{l}\text { Bowkerieae } \\
\text { (Oxelman et al. 2005; Tank et } \\
\text { al. 2006) }\end{array}$ & Anastrabe (1), Bowkeria (5), Ixianthes (1) & Rediviva & $\begin{array}{l}\text { Vogel 1974; Steiner \& Whitehead 1990; 1991; } \\
\text { 1996;Whitehead \& Steiner 1992; Steiner } 1993\end{array}$ \\
\hline
\end{tabular}


Table 1. Cont.

\begin{tabular}{|c|c|c|c|c|c|}
\hline \multicolumn{3}{|c|}{ Taxonomic classification* } & $\begin{array}{l}\text { Taxa with oil-offering flowers in at least one } \\
\text { species (total of species in the genus) }{ }^{* *}\end{array}$ & Genus of oil-collecting bees & References \\
\hline 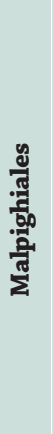 & & 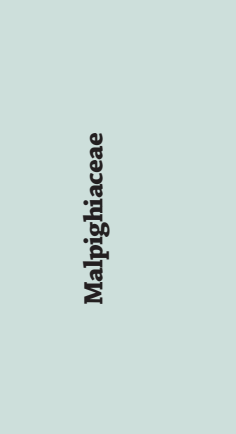 & $\begin{array}{l}\text { Most of the neotropical genera } \\
(\approx 1100 \text { spp.: e.g. Acmanthera, Aspicarpa, } \\
\text { Banisteriopsis, Barnebya, Blepharanda, Bunchosia, } \\
\text { Burdachia, Byrsonima, Callaeum, Camarea, } \\
\text { Clonodia, Cordobia, Diacidia, Dicella, Dinemagonum, } \\
\text { Dinemandra, Diplopterys, Galphimia, Gaudichaudia, } \\
\text { Glandonia, Heladena, Henleophytum, Heteropterys, } \\
\text { Hiraea, Janusia, Lophanthera, Lophopterys, } \\
\text { Lubelina, Malpighia, Mascagnia, Mcvaughia, } \\
\text { Mezia, Peixotoa, Peregrina, Pterandra, Spachea, } \\
\text { Stigmaphyllon, Tetrapterys, Tricomaria, Triopterys, } \\
\text { Verrucularia) }\end{array}$ & $\begin{array}{l}\text { Centris, Epicharis, Monoeca, Paratetrapedia, } \\
\text { Tetrapedia }\end{array}$ & $\begin{array}{l}\text { Vogel 1974; Lorenzo 1981; Steiner 1985a; } \\
\text { Buchmann 1987; Lobreau-Callen 1989; Sazima } \\
\text { \& Sazima 1989; Simpson 1989; Anderson 1990; } \\
\text { Barros 1992; Mamede 1993; Cocucci et al. 1996; } \\
\text { Vinson et al. 1997; Teixeira \& Machado 2000; } \\
\text { Castro et al. 2001; Seipold et al. 2004; Sigrist \& } \\
\text { Sazima 2004; Carvalho et al. 2005; Benezar \& } \\
\text { Pessoni 2006; Costa et al. 2006; Oliveira et al. } \\
\text { 2007; Reis et al. 2007; Vilhena \& Augusto 2007; } \\
\text { Ribeiro et al. 2008; Bezerra et al. 2009; Dunley et } \\
\text { al. 2009; Amorim \& Marco 2011; Cappellari et al. } \\
\text { 2011; Mendes et al. 2011; Possobom 2013; Sazan } \\
\text { et al. 2013; Possobom et al. 2015 }\end{array}$ \\
\hline 憘 & 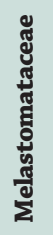 & $\begin{array}{c}\text { Olisbeoideae } \\
\text { (sensu Stone 2006) }\end{array}$ & Mouriri myrtilloides subsp. parvifolia $a^{* * *}$ & Paratetrapedia & Buchmann \& Buchmann 1981 \\
\hline $\begin{array}{l}\text { हैँ } \\
\text { हैँ } \\
\text { के }\end{array}$ & 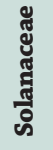 & Petunioideae & Nierembergia (21) & $\begin{array}{l}\text { Centris, Chalepogenus, Lanthanomelissa, } \\
\text { Paratetrapedia, Tapinotaspis }\end{array}$ & $\begin{array}{l}\text { Simpson \& Neff 1981; Cocucci 1991; Cosacov et } \\
\text { al. 2008; Tate et al. 2009; Nattero et al. } 2010\end{array}$ \\
\hline 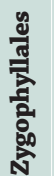 & & Krameriaceae & Krameria (18) & Centris & $\begin{array}{l}\text { Vogel 1974; Simpson et al.1977; Seigler et al. } \\
\text { 1978; Simpson \& Neff 1981; Simpson 1982; } \\
\text { 2007; Simpson \& Saliwon 1999; Simpson et } \\
\text { al. 2004; Gimenes \& Lobão 2006; Carneiro et } \\
\text { al. } 2015\end{array}$ \\
\hline
\end{tabular}

* Except in cases where the source is specified between parentheses, the taxonomic classification is based on Stevens (2001).

${ }^{* *}$ The presence of oil secretion is based on studies on morphology, chemistry and/or pollination ecology. The number of species of each genus is based on The Plant List (2013), Chase et al. (2015, for Orchidaceae) or on the cited references.

***There is not enough information to assume that the oil-secreting structures really act as elaiophores in these species. 


\section{Clivia Carolina Fiorilo Possobom and Silvia Rodrigues Machado}

Table 2. Location and morphology of the oil-secreting structures in the plant taxa for which we were able to find published information.

\begin{tabular}{|c|c|c|c|}
\hline Taxa & & Gland morphology and location & Reference \\
\hline \multirow{5}{*}{$\begin{array}{l}\text { Asparagales } \\
\text { Iridaceae }\end{array}$} & Alophia tigridioides & \multirow{3}{*}{ UT - adaxial surface of the inner tepals } & \multirow{3}{*}{ Vogel 1974} \\
\hline & Cypella herbertii & & \\
\hline & $\begin{array}{l}\text { Ennealophus euryandrus } \\
\text { (=Sphenostigma euryandra) }\end{array}$ & & \\
\hline & Sisyrinchium spp. & $\begin{array}{l}\text { UT - adaxial surface of the inner tepals or } \\
\text { along stamen column }\end{array}$ & $\begin{array}{l}\text { Vogel 1974; Rudall et al. 2003; } \\
\text { Cocucci \& Vogel 2001; Chaveau et al. } \\
\text { 2011; Silvério et al. } 2012\end{array}$ \\
\hline & Tigridia meleagris & UT - adaxial surface of the inner tepals & Rudall et al. 2003 \\
\hline \multirow{34}{*}{$\begin{array}{l}\text { Asparagales } \\
\text { Orchidaceae }\end{array}$} & Ceratandra spp. & E - Callus & Steiner 1998 \\
\hline & Cyrtochilum meirax & CE - not clear & Davies et al. 2014 \\
\hline & Gomesa bifolia & CE - Callus & Aliscioni et al. 2009 \\
\hline & Gomesa echinata & PE - Callus & Stpiczyńska et al. 2013 \\
\hline & Gomesa flexuosa & CE/UT - Callus & Gomiz et al. 2013 \\
\hline & $\begin{array}{l}\text { Gomesa loefgrenii } \\
\text { (as Oncidium loefgrenii) }\end{array}$ & PE - Callus & Stpiczyńska et al. 2007 \\
\hline & Gomesa longipes & CE/UT - Callus & Davies et al. 2014 \\
\hline & $\begin{array}{l}\text { Gomesa paranensoides } \\
\text { (as Oncidium paranaense) }\end{array}$ & CE - lateral lobes of the labellum & Singer \& Cocucci 1999 \\
\hline & $\begin{array}{c}\text { Gomesa radicans } \\
\text { (as Ornithophora radicans) }\end{array}$ & PE - Labellum/callus complex & Stpiczyńska \& Davies 2008 \\
\hline & Gomesa ranifera & PE - Callus & Stpiczyńska et al. 2013 \\
\hline & Gomesa recurva & E - Labellum & Stpiczyńska et al. 2007 \\
\hline & Gomesa riograndensis & PE - Callus & Gomiz et al. 2013 \\
\hline & Gomesa varicosa & CE - Callus & Gomiz et al. 2013 \\
\hline & $\begin{array}{c}\text { Gomesa venusta } \\
\text { (as Oncidium trulliferum) }\end{array}$ & $\begin{array}{c}\text { PE - lateral lobes of the labellum and } \\
\text { callus }\end{array}$ & Stpiczyńska \& Davies 2008 \\
\hline & Grobya amherstiae & $\begin{array}{l}\mathrm{PE} / \mathrm{UT} \text { - apex of the labellum, UT - base } \\
\text { of the column, E - abaxial surface of the } \\
\text { labellum (oil guide) }\end{array}$ & Pansarin et al. 2009 \\
\hline & Lockhartia spp. & UT - Callus & Blanco et al. 2013 \\
\hline & Oncidium amazonicum & PE - Callus & Stpiczyńska et al. 2013 \\
\hline & $\begin{array}{l}\text { Oncidium bicallosoides } \\
\text { (as Sigmatostalix bicallosa) }\end{array}$ & PE- Callus & Vogel 1974 \\
\hline & Oncidium cheirophorum & CE - lateral lobes of the labellum & Pacek \& Stpiczyńska 2007 \\
\hline & Oncidium heteranthum & CE/UT - Callus & Davies et al. 2014 \\
\hline & Oncidium ornithorhynchum & PE - lateral lobes of the labellum & Vogel 1974; Davies \& Stpiczyńska 2009 \\
\hline & Oncidium oxyceras & PE - Callus & Stpiczyńska et al. 2013 \\
\hline & Oncidium sect.Cyrtochilum & PE - Labellum & Vogel 1974 \\
\hline & $\begin{array}{l}\text { Ornithocephalus ciliatus } \\
\text { (as Ornithocephalus kruegeri) }\end{array}$ & UT - Callus & Pacek \& Stpiczyńska 2007 \\
\hline & Ornithocephalus gladiatus & CE/UT - lateral lobes of the labellum & Pacek et al. 2012 \\
\hline & Phymatidium falcifolium & UT - Callus & Pacek et al. 2012 \\
\hline & Rudolfiella picta & PE - Callus & Davies \& Stpiczyńska 2009 \\
\hline & Trichocentrum cavendishianum & $\mathrm{PE}$ - lateral lobes of the labellum & Stpiczyńska et al. 2007 \\
\hline & Trichocentrum pumilum & UT - lateral lobes of the labellum & Pansarin \& Pansarin 2011 \\
\hline & Vitekorchis excavata & CE/UT -Callus & Davies et al. 2014 \\
\hline & Zygostates alleniana & $\begin{array}{l}\text { UT - central and lateral lobes of the } \\
\text { labellum }\end{array}$ & Gomiz et al. 2014 \\
\hline & Zygostates grandiflora & UT - Callus & Pacek et al. 2012 \\
\hline & Zygostates lunata & UT - Callus & Pacek et al. 2012 \\
\hline & Zygostates pustulata & UT - Callus & Vogel 1974 \\
\hline \multirow{3}{*}{$\begin{array}{l}\text { Cucurbitales } \\
\text { Cucurbitaceae }\end{array}$} & Indofevillea jiroi & $\mathrm{T}$ - base of the inner surface of the five petals & Schaefer et al. 2012 \\
\hline & Momordica spp. & $\begin{array}{c}\mathrm{T} \text { - base of the inner surface of one or } \\
\text { three petals }\end{array}$ & \multirow[t]{2}{*}{ Vogel 1988} \\
\hline & Thladiantha spp. & $\mathrm{T}$ - base of the inner surface of the five petals & \\
\hline
\end{tabular}


Table 2. Cont.

\begin{tabular}{|c|c|c|c|}
\hline \multicolumn{2}{|l|}{ Taxa } & \multirow{2}{*}{$\begin{array}{l}\text { Gland morphology and location } \\
\text { MT - base of the inner surface of the } \\
\text { petals and of the anther filaments }\end{array}$} & \multirow{2}{*}{$\begin{array}{c}\text { Reference } \\
\text { Simpson et al. 1983; Vogel } 1986 \text { (apud } \\
\text { Buchmann 1987) }\end{array}$} \\
\hline $\begin{array}{l}\text { Ericales } \\
\text { Primulaceae }\end{array}$ & Lysimachia spp. & & \\
\hline $\begin{array}{c}\text { Lamiales } \\
\text { Calceolariaceae }\end{array}$ & Calceolaria spp. & MT - inside the saccate lower lip & Vogel 1974; Sérsic 2004 \\
\hline \multirow{2}{*}{$\begin{array}{c}\text { Lamiales } \\
\text { Plantaginaceae }\end{array}$} & Angelonia spp. & MT - inside the two sacs of the lower lip & Vogel 1974; Vogel \& Machado 1991; \\
\hline & Monttea spp. & MT - in the two depressions of the lower lip & Simpson et al. 1990; Sérsic \& Cocucci 1999 \\
\hline \multirow{4}{*}{$\begin{array}{l}\text { Lamiales } \\
\text { Scrophulariaceae }\end{array}$} & Alonsoa unilabiata & $\begin{array}{l}\text { MT - on the two shallow sacs on the base of } \\
\text { the lateral lobes (upper side of the corolla) }\end{array}$ & Steiner 1989 \\
\hline & Colpias mollis & $\begin{array}{l}\text { MT - on the paired sacs on the base of the } \\
\text { corolla lobes at the lower side of the tube. }\end{array}$ & Vogel 1974; Steiner \& Whitehead 2002 \\
\hline & Diascia spp. & $\begin{array}{l}\text { MT - inside paired spurs of different } \\
\text { lengths at the lower side of the corolla }\end{array}$ & Vogel 1974; 1984 \\
\hline & Hemimeris racemosa & $\begin{array}{l}\text { MT - around the entrance of two shallow } \\
\text { sacs at the base of the dorsal corolla lobe. }\end{array}$ & Pauw 2005 \\
\hline Lamiales Stilbaceae & Bowkeria verticillata & MT - inside the saccate lower lip & Vogel 1974 \\
\hline \multirow{12}{*}{$\begin{array}{l}\text { Malpighiales } \\
\text { Malpighiaceae }\end{array}$} & Banisteriopsis spp. & \multirow{12}{*}{$\begin{array}{l}\mathrm{PE} \text { - in pairs on the abaxial } \\
\text { surface of four or five sepals }\end{array}$} & Araújo \& Meira 2016; Possobom 2013 \\
\hline & Byrsonima coccolobifolia & & Possobom 2013 \\
\hline & Camarea affinis & & Mamede 1993 \\
\hline & Dinemandra ericoides & & Cocucci et al.1996 \\
\hline & Diplopterys pubipetala & & Possobom et al. 2015 \\
\hline & Galphimia brasiliensis & & Castro et al. 2001 \\
\hline & Heteropterys chrysophylla & & Vogel 1974 \\
\hline & Hiptage sericea & & Subramanian et al.1990 \\
\hline & Janusia guaranitica & & Lorenzo 1981 \\
\hline & Malpighia spp. & & Vogel 1974; Laskowsky \& Bautista 1999 \\
\hline & Peixotoa reticulata & & Possobom 2013 \\
\hline & Stigmaphyllon littorale & & Vogel 1974 \\
\hline $\begin{array}{l}\text { Solanales } \\
\text { Solanaceae }\end{array}$ & Nierembergia spp. & $\begin{array}{l}\text { MT - inside corolla tube and on the base } \\
\text { of the anther filaments }\end{array}$ & Cocucci 1991 \\
\hline $\begin{array}{l}\text { Zygophyllales } \\
\text { Krameriaceae }\end{array}$ & Krameria spp. & PE - on the two modified petals & Vogel 1974; Simpson 1982 \\
\hline
\end{tabular}

$\mathrm{T}$ = trichomal elaiophore; $\mathrm{E}$ = epithelial elaiophore (no differentiation was made by the author); UT = unicellular trichomes; MT = multicellular trichomes; $C E$ = cuboid epithelial cells; $\mathrm{PE}$ = palisade-like epithelial cells.

and the tepals, while in the other two tribes they occur only on the tepals, generally on the inner ones (Goldblatt et al. 1998; Chaveau et al. 2011; 2012; Silvério et al. 2012; Fig. 1A). Trichomes on both inner and outer tepals occur in Herbertia species (Tigridieae) (Chaveau et al. 2012). Although most of these Iridoideae members have oil-producing trichomes, they are absent or are nectar-producing in some species (Chaveau et al. 2012).

Only one Old World representative of the Crocoideae subfamily seems to produce floral oil (Manning \& Goldblatt 2002; see Tabs. 1, 2). Unlike the Iridoideae members, Tritoniopsis parviflora flowers are bilaterally symmetrical and, in addition to the septal nectary, have epithelial elaiophores located over the proximal parts of the perianth (Manning \& Goldblatt 2002).

The first morphological description of the elaiophores in Iridaceae was made by Vogel (1974) in some Cypella, Alophia, Ennealophus (as Sphenostigma) and Sisyrinchium species (Tab. 2). In addition to that study, data on these glands is restricted to other Sisyrinchium species (Cocucci \& Vogel 2001; Chaveau et al. 2011; 2012; Silvério et al. 2012), Tritoniopsis parviflora (Manning \& Goldblatt 2002) and very few species of the Trimezieae and Tigridieae (Chaveau et al. 2012) (Tab. 2). Most of these authors carried out superficial analyses using light microscopy and/or histochemical tests. Vogel (1974), Cocucci \& Vogel (2001) and Manning \& Goldblatt (2002) also provided data on pollination ecology.

The trichomes are unicellular, elongated and with a wide (capitate) apex (see Vogel 1974; Cocucci \& Vogel 2001; Silvério et al. 2012). In most species a subcuticular space is formed at the apex of the trichome where the oil is accumulated before its release by cuticular rupture. When this space is absent, the oil apparently permeates the intact cuticle (see Vogel 1974; Cocucci \& Vogel 2001). Among the taxa, differences seem to occur in the length, shape and curvature of the trichomes, as well as in the thickness of the cell walls and cuticle (see Vogel 1974; Cocucci \& Vogel 2001; Chaveau et al. 2011; Silvério et al. 2012). 

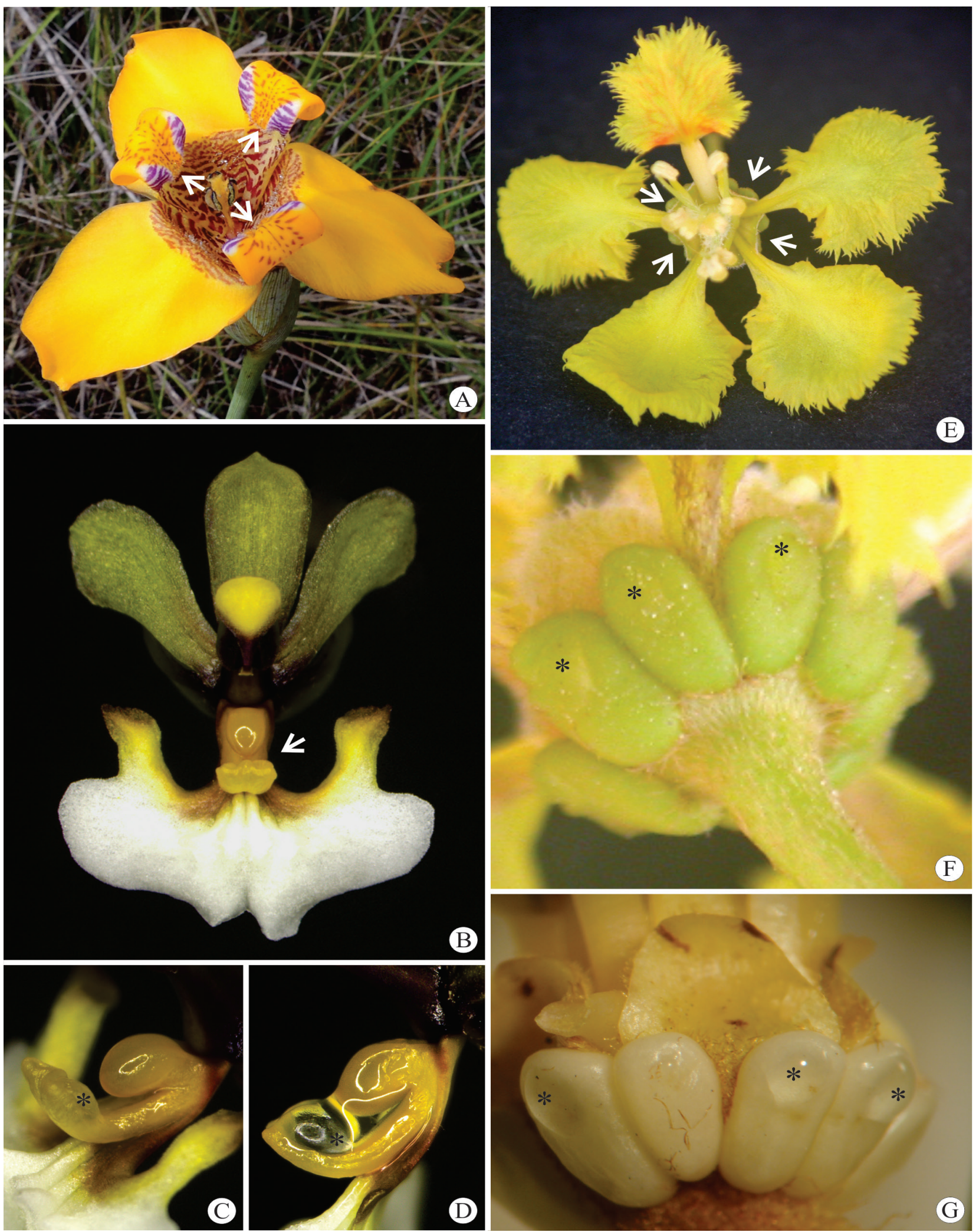

Figure 1. Location of the oil-secreting structures in flowers of the Iridaceae, Orchidaceae and Malpighiaceae species. A. Trimezia sp. (Iridaceae). Note the three inner tepals where the supposed oil-secreting trichomes occur (arrows). B -D. Gomesa radicans (syn. Ornithophora radicans, Orchidaceae). B. Note the conspicuous epithelial elaiophore on the callus (arrows). C. Prominent subcuticular space where the oil accumulates $\left({ }^{*}\right)$. D. Abundant secretion on elaiophores. E-F. Diplopterys pubipetala (Malpighiaceae). Note the paired epithelial elaiophores on the calyx (arrows). G. Epithelial elaiophores on the calyx of Byrsonima coccolobifolia. $\left({ }^{*}\right)$ indicates the hyaline secretion on the distal region of the glands. Photos (B-D): Sérgio Akira Adachi. 
The epithelial elaiophores have not yet been investigated comprehensively. Manning \& Goldblatt (2002) suggested the lipidic secretion covers the outer surface of the perianth tube and the basal part of the claws of all tepals. They also supposed the presence of epithelial elaiophores, since they did not observe trichomes in these flowers.

No data on cellular ultrastructure is available for elaiophores of the Iridaceae species.

Some information on the chemical nature of the oil from Iridaceae species was provided by Vogel (1974) and Simpson \& Neff (1981). Free fatty acids and acylglycerols seem to be the main components of the oil.

Centridini (Centris) and Tapinotaspidini (Chalepogenus, Lanthanomelissa, Paratetrapedia and Tapinotaspis) bees seem to be the most frequent visitors of the New World Iridaceae (see Vogel 1974; Buchmann 1987; Cocucci \& Vogel 2001; Alves-dos-Santos et al. 2007).These bees land on the perianth or on the column and flex to collect the oil from the trichomes, generally with their front legs, while they contact the reproductive parts with the ventral (sternotribic pollination) or dorsal (nototribic pollination) surfaces of their heads, thoraxes or abdomens (see Vogel 1974; Cocucci \& Vogel 2001). The oil-collecting bee Rediviva gigas (Melittidae) has been observed visiting flowers of the African T. parviflora (Manning \& Goldblatt 2002) but the authors do not provide any further detail about its behavior in relation to elaiophores.

\section{Orchidaceae}

Orchidaceae, one of the largest families of the angiosperms, is cosmopolitan and has 880 genera and 27800 species (Stevens 2001). The flowers can be deceptive or they can offer different resources for their pollinators such as nectar, fragrances, and oils (see Singer 2003). Pollinators include bees, wasps, hummingbirds, moths and flies (see Singer 2003).

According to Renner \& Schaefer (2010) the family shows many more than 12 independent origins for oil flowers, most represent the youngest lineages to produce oil as a floral reward.

Oil-producing species seem to be restricted to a few subtribes of the Epidendroideae and the Orchidoideae (sensu Chase et al. 2015), including New World and African species (see Tab. 1). In such taxa, the oil glands occupy different positions on the flowers and they have no simple morphological pattern being of the epithelial and/or trichomal types (Tab. 2).

Most species bearing elaiophores, belong to the neotropical Oncidiinae, which includes 61 genera and 1600 species and a great diversity of pollination systems (Neubig et al. 2012; Tab. 1). The flowers of several species can either reward their pollinator with oil or mimic the Malpighiaceae oil flowers and perhaps also the Calceolariaceae ones (see Neubig et al. 2012). In this subtribe, the oil-secreting organs most often occur on the two lateral lobes of the labellum or on the callus (Neubig et al. 2012, Tab.2, Fig.1). In the South African Coryciinae, the oil is generally secreted from the tip of the labellum appendage (Waterman et al. 2009), while in Huttonaea (Disinae) there are generally multicellular verrucae in each of the two petal sacs which secrete oil (Steiner 2010). For other subtribes with oilproducing flowers there is little information or such as there it is restricted to just a few species (e.g. Brownleeinae, Catasetinae, Cranichidinae, Maxillariinae, Orchidinae; Tab.1).

Structural aspects of the elaiophores were first described by Vogel (1974) in Zygostates and Oncidium (including one Sigmatostalix) species (Tab. 2). Since then, about 50 species, almost all Oncidiinae members, have been studied in relation to the morphology, histochemistry and ultrastructure of their elaiophores (see Tab.2).

Trichomal elaiophores are generally constituted by a set of unicellular hairs which may occupy one or two distinct areas (Vogel 1974; Pacek \& Stpiczyńska 2007; Pansarin et al. 2009; Pacek et al. 2012; Blanco et al. 2013; Gomiz et al. 2014). The trichomes can be either short (Pansarin et al. 2009; Pacek et al. 2012; Blanco et al. 2013) or elongated (Vogel 1974; Pacek \& Stpiczyńska 2007; Pansarin et al. 2009; Pansarin \& Pansarin 2011; Pacek et al.2012; Blanco et al. 2013; Gomiz et al. 2014). These unicellular trichomes have uniform width in most species but are capitate in Phymatidium falcifolium (Pacek et al. 2012). In Lochartia species they can be capitate, bifid or branched at the apex (Blanco et al. 2013).

The epithelial elaiophores are generally constituted by one layer of cuboid (Singer \& Cocucci 1999; Pacek \& Stpiczyńska 2007; Pacek et al. 2012; Gomiz et al. 2013; Davies et al. 2014) or palisade-like (Stpiczyńska et al. 2007, Stpiczyńska \& Davies 2008; Davies \& Stpiczyńska 2009; Gomiz et al. 2013; Stpiczyńska et al. 2013) epithelial cells which are covered by a cuticle. Sometimes the elaiophore presents a wrinkled surface as in Oncidium cheirophorum (Pacek \& Stpiczyńska 2007). Below the secretory epithelium can have a few layers (1-3) of subepithelial parenchyma (Pacek \& Stpiczyńska 2007; Stpiczyńska et al. 2007; Stpiczyńska \& Davies 2008; Aliscioni et al. 2009; Davies \& Stpiczyńska 2009; Pacek et al. 2012; Gomiz et al. 2013; Stpiczyńska et al. 2013) and also a ground vascularized parenchyma (Pacek \& Stpiczyńska 2007; Aliscioni et al. 2009; Davies \& Stpiczyńska 2009; Pacek et al. 2012; Stpiczyńska et al. 2013). In Oncidium ornithorhynchum the subepithelial parenchyma is unusual, since it shows well-developed intercellular spaces, where a flocculent material accumulates in the pre-secretory stage (Davies \& Stpiczyńska 2009).

Most of species have well-defined epithelial elaiophores (Pacek \& Stpiczyńska 2007; Stpiczyńska et al. 2007; Stpiczyńska \& Davies 2008; Aliscioni et al. 2009; Davies \& Stpiczyńska 2009; Pacek et al. 2012; Gomiz et al. 2013; Stpiczyńska et al. 2013) but some, such as Gomesa recurva 
(Stpiczyńska et al. 2007) and Cyrtochilum meirax (Davies et al. 2014) have morphologically undifferentiated, constituted by oval or cuboid epithelial cells, lacking secretory features such as a dense and abundant cytoplasm.

Flowers of Grobya amherstiae represent an interesting example, since they have three types of oil-secreting structures, classified as elaiophores by researchers (Pansarin et al. 2009). According to these authors, the elaiophores are trichomal on the column base, epithelial but poorly differentiated on the internal surface of the labellum, and both epithelial and trichomal at the apex of the labellum. Considering that the secretion of the internal portion of the labellum is not collected by the pollinator Paratetrapedia fervida (Mickeliunas et al. 2006), the authors suggest such elaiophores act as a guide to the bees (Pansarin et al. 2009). It is important to emphasize that it is not possible to classify this structure as a true elaiophore, since the meaning of the term is not restricted just to secretion of oil but also to reward to pollinators.

As in G. amherstiae (Pansarin et al. 2009), other Orchidaceae species have oil-secreting areas on the labellum that are constituted by a glabrous epithelium besides papillose and/or elongated (trichome-like) cells. Such structures were interpreted as intermediate elaiophores and have been described in Ornithocephalus gladiatus (Pacek et al. 2012), Gomesa flexuosa (Gomiz et al. 2013), Gomesa longipes, Vitekorchis excavata and Oncidium heteranthum var. album (Davies et al. 2014).

Davies et al. (2014) characterized the appearance of the secretions of some species as "wax-like heterogeneous" (G. longipes), "wax-like" (V. excavata), "oil-like" (O. heteranthum var. album) and "oil-like, but more volatile" (Cyrtochilum meirax). These features associated with the absence of information about the visitor behavior, raise the question whether all of the oil-secreting structures they describe are truly elaiophores.

In most plant species the lipidic secretion accumulates beneath the cuticle before its release (Singer \& Cocucci 1999; Pacek \& Stpiczyńska 2007; Stpiczyńska et al. 2007; Stpiczyńska \& Davies 2008; Pacek et al. 2012; Stpiczyńska et al. 2013). Generally the secretions are released after cuticle rupture, sometimes triggered only by floral visitors (Stpiczyńska et al. 2007; Stpiczyńska \& Davies 2008; Pacek et al. 2012; Stpiczyńska et al. 2013). However, in some species the authors did not observe the detachment or disruption of the cuticle, suggesting that the secretion passes through the cell wall and cuticle (Aliscioni et al. 2009; Pansarin \& Pansarin 2011; Davies et al. 2014).

The ultrastructural features of the secretory cells are very similar among species (Stpiczyńska et al. 2007; Stpiczyńska \& Davies 2008; Aliscioni et al. 2009; Davies \& Stpiczyńska 2009; Pacek et al. 2012; Blanco et al. 2013; Davies et al. 2014). In general, the secretory cells have central nuclei and dense cytoplasms with a predominance of endoplasmic reticulum, numerous mitochondria, plastids with plastoglobuli and lipid droplets. Vacuoles with myelin-like figures, plastids with starch grains, dyctiosomes and vesicles near or in fusion with the plasmalena are also commonly described in the elaiophores of Orchidaceae species. In some species there are secretion-filled cavities on the outer periclinal cell wall which is covered by a lamellate and/or reticulate cuticle. In epithelial elaiophores, a dissolution of the middle lamella sometimes occurs between adjacent cells, and here the secreted material accumulates.

Information on floral oil composition is available for the following species: Oncidium pubes (Reis et al. 2000), Gomesa radicans (as Ornithophora radicans; Reis et al. 2003), Phymatidium tillandsioides and P. delicatulum (Reis et al. 2006). Acylglycerols, diacylglycerols or triacylglycerols predominate in the floral oil of several of these species.

The South American oil-producing orchids seem to be pollinated mainly by Centridini (Centris), Tapinotaspidini (Lophopedia, Paratetrapedia) and Tetrapediini (Tetrapedia) bees (Vogel 1974; Singer \& Cocucci 1999; Mickeliunas et al. 2006; Pansarin \& Pansarin 2011; Torretta et al. 2011; Tab. 1). Pacek et al. (2012) hypothesized that trichomal elaiophores may best suit smaller bees, such as the Paratetrapedia species, which collect the secretion with delicate movements, whereas the epithelial elaiophores may best suit larger bees, such as Centris species, which hold the tabula infrastigmatica with their mandibles while collecting the oil with their front or middle legs. During an oil-collection visit, the pollinarium can attach to the heads of Centris (Torreta et al. 2011) or Tetrapedia (Singer \& Cocucci 1999) bees or to the dorsal surface of the thoraxes (scutellum) of Paratetrapedia bees (Mickeliunas et al. 2006).

The South African oil-producing species are pollinated by Rediviva (Melittidae) bees, which use their front legs to collect the oil from trichomal or epithelial elaiophores on the labellum appendages or from the verrucae on the petal sacs (Manning \& Linder 1992; Whitehead \& Steiner 1992; 1993; Pauw 2006; Whitehead et al. 2008; Steiner 2010; Tab. 1). The pollinarium of some of these Orchidaceae species can attach to the ventral surface of the abdomen, thorax or to several sites on the front, middle or hind legs of the Rediviva bees (Manning \& Linder 1992; Pauw 2006; Steiner 2010).

Although studies of oil flowers in orchids remain scarce, data show in general that the elaiophores exhibit great diversity in terms of location, morphology and release mechanisms. Based on this diversity, Davies \& Stpiczyńska (2009) postulated that the elaiophores probably evolved in response to pollinator pressures.

\section{Cucurbitales}

\section{Cucurbitaceae}

Cucurbitaceae is a tropical and subtropical family with 98 genera and 1000 species (Stevens 2001). The flowers are actinomorphic and generally unisexual and the species are monoecious or dioecious (Schaefer \& Renner 2010; 2011). 
Nectar, pollen and occasionally oil are the rewards for floral visitors (Nepi \& Paccini 1994; Vogel 2009) which are mainly bees, but also bats, hawkmoths, flies and butterflies (see Schaefer \& Renner 2011 and references therein).

Renner \& Schaefer (2010) show that the floral oil evolved only once (57-42 myr) but was lost at least six times in this family. So far, oil flowers are known or suspected in six genera belonging to the Joliffieae grade (sensu Kocyan et al. 2007; Tab. 1) whose species predominate in the Old World: Momordica, Thladiantha (Vogel 1976b; 1981; 1988; 2009; Schaefer \& Renner 2011), Baijiania, Siraitia, Telfairia (see Renner \& Schaefer 2010; Schaefer \& Renner 2011; Schaefer et al. 2012) and Indofevillea (Schaefer et al. 2012).

According to Vogel (1988) the male flowers of Momordica and Thladiantha produce nectar and oil, while the female flowers produce only oil, and in lower amounts than the male flowers (Vogel 1988). The oil-secreting trichomes form dense covers on the base of all five petals (Thladiantha and Indofevillea) or of 1-3 petals (Momordica) (Vogel 1988; Schaefer et al. 2012, Tab. 2).

In our survey we were unable to find detailed information on glandular trichome morphology, secretory processes and/or chemical analyses of the secretions. Some detailed information about elaiophore morphology of Momordica and Thladiantha species is likely provided by Vogel (1976b; 1990b) but we were unable to access these publications.

Ctenoplectra (Ctenoplectrini) bees are the main visitors of the oil-producing Cucurbitaceae species (Vogel 1981; 1988; Schaefer \& Renner 2008; Sung et al. 2009, Tab.1). To collect the oil, these bees mop the surface of the elaiophore with their abdominal (metasomal) brushes (Vogel 1981; 1988). While they collect the oil from the male flowers, the pollen grains can stick to the dorsal surfaces of their bodies.

\section{Ericales}

\section{Primulaceae}

The Primulaceae is a cosmopolitan family with 58 genera and 2590 species (Stevens 2001). The flowers are actinomorphic, pollinated by bees or flies and they have nectar and pollen as the main rewards (Anderberg 2004; Stahl \& Anderberg 2004).

Oil flowers also occur but are restricted to the Lysimachia (Tabs. 1, 2), a genus that includes approximately 180 morphologically diverse and widespread species most of which occur throughout the temperate and subtropical regions of the Northern Hemisphere (see Hao et al. 2004; Anderberg et al. 2007).

Since 1976 (Vogel 1976a) it is known that some Lysimachia species have glandular trichomes whose secretions are collected by bee species of the Holartic genus Macropis (Melittidae). Simpson et al. (1983) provided some data on the glandular trichomes of Lysimachia species, especially in the L. ciliata. In 1986, Vogel provided detailed structural and ultrastructural characterization of the secretory trichomes of several Lysimachia species, as well as microchemical analyses of their secretions (see Buchmann 1987; Anderberg et al. 2007). He found oil-producing trichomes in 78 Lysimachia species (see Buchmann 1987).

The oil-producing trichomes are multicellular, capitate and located on the basal part of the petals or of the anther filaments (Vogel 1976a; Simpson et al. 1983, Tab.2). They comprise a stalk with one to three cells and a head with 8 or 16 cells (Simpson et al. 1983). The secretion is accumulated in the subcuticular space formed by the detachment of the cuticle from the outer periclinal cell wall (Simpson et al. 1983).

Among other components, fatty acids and diglycerides have already been detected in the floral oil from Lysimachia species (Simpson \& Neff 1981; Cane et al. 1983; Simpson et al. 1983; Buchmann 1987).

Females of the oil-collecting Macropis (Melittidae) bees are the pollinators of the oil flowers of Lysimachia (Vogel 1976a, Tab. 1). Cane et al. (1983) provided the first evidence of the use of the floral oil of L. ciliata by Macropis nuda bees as a brood-cell lining, in addition to its role as larval provision. These bees landed on the androecium, curled around the anthers and mopped the glandular trichomes with their front and middle legs to collect the oil (Cane et al. 1983; Vogel 1986 apud Buchmann 1987; Vogel 1988). Pollen grains are collected sternotribically (Cane et al. 1983).

To understand how the Macropis bees find the Lysimachia plants, Dötterl \& Schäffler (2007) analyzed the scents emitted by the green parts, flowers, and pure oil of $L$. punctata. These authors found evidence that the aromatic compounds detected in the oil and in the flowers may be responsible for the attraction of the oil-collecting bee $M$. fulvipes. Schäffler et al. (2012) showed that the floral scents of Lysimachia oil-producing species has lower variability than the non-oil species and they also found a correlation between the yellow flowers (bee-green) and oil secretion. Thus, such authors also provide evidence that floral scents and colors of Lysimachia species are under selection by Macropis bees.

\section{Lamiales}

\section{Calceolariaceae}

Calceolariaceae comprises two genera, Calceolaria and Jovellana, and 260 species (Stevens 2001). Calceolaria species are restricted to the Andes region while Jovellana species (six spp.) occur in Chile and New Zealand (Andersson 2006). In this family, the melittophily is predominant, with pollen or oil as floral rewards (Molau 1988; Sérsic 2004).

Oil is restricted to Calceolaria (see Tabs. 1, 2) which, according to Renner \& Schaefer (2010), is one of the youngest lineages to offer this floral resource with at least six independent losses of this character. The flowers of the Calceolaria species have a bilabiate and generally yellow 
corolla, most of them with a set of oil-producing trichomes on the edge of the abaxial surface, facing the inside of the saccate lower lip (Vogel 1974; Molau 1988; Andersson 2006; Mayr \& Weber 2006; Cosacov et al. 2009). According to Sérsic (2004) approximately $18 \%$ ( $~ 49$ spp.) of the Calceolaria species lack oil glands.

The most comprehensive study of the floral biology and pollination of the Calceolaria species was carried out by Sérsic (2004). Information on the structure, ultrastructure, and chemical compositions of the secretions and on the elaiophores visitors of the Calceolaria species was also provided by Vogel (1974), in addition to Sérsic (2004).

The elaiophores may vary in terms of location, size, shape, trichome density and cell number (Vogel 1974; Sérsic 2004). In general, the trichomes are multicellular and comprise a stalk and a glandular head. The stalk is uniseriate and has from one to eight highly-vacuolated cells with chloroplasts. The apical cell of the stalk, the neck cell, has a cutinized cell wall. The head is formed by four to 35 radially-distributed cells with small vacuoles and dense and abundant cytoplasms (Vogel 1974; Sérsic 2004). The secretion accumulates beneath the cuticle, where generally no pores are visible (Sérsic 2004).

According to Schnepf (1969), the secretory cells have dense cytoplasm with numerous poorly differentiated leucoplasts generally enveloped by cisternae of the endoplasmic reticulum, in addition to dictyosomes that predominate in younger stages.

Vogel (1974) found diacylglycerol of acetic acid and $\beta$-acetoxy palmitic acid as the main compounds of the oil of Calceolaria pavonii, besides non-volatile isoprenoid compounds and some trisaccharides. Using thin-layer chromatography, Sérsic (2004) and Cosacov et al. (2012) show that the floral oils are mixtures of different lipid fractions, but the compounds were not identified.

Centridini (Centris) and Tapinotaspidini (Chalepogenus, Tapinotaspis) bees are the main visitors of the Calceolaria species (Vogel 1974; Rasmussen \& Olesen 2000; Sérsic 2004; Cosacov et al. 2012; 2014; Murúa et al. 2014, Tab 1 ). The oil is generally collected with the front legs and it is transferred to the hind legs during flight (Sérsic 2004).

There are different flower morphotypes according to the visitor for Chalepogenus (Tapinotaspidini) or Centris (Centridini) bees (Molau 1988; Sérsic 2004). A Tapinotaspidini flower normally has a small hooded upper lip, short stamens and a flattened lower lip that functions as a landing surface for the small Chalepogenus bees (Molau 1988; Sérsic 2004). The opening of this flower is small, the elaiophores are easily accessible and the pollination is always nototribic (Molau 1988; Sérsic 2004). The Centridini flowers can be open (wide opening) or closed and they generally have an inflated and non-flattened lower lip. The pollination is nototribic in open flowers and can be nototribic or sternotribic in closed flowers (Molau 1988; Sérsic 2004).

\section{Plantaginaceae}

The Plantaginaceae is a cosmopolitan family predominant in temperate regions with approximately 90 genera and 1900 species (Stevens 2001). The flowers are zygomorphic, morphologically diverse and can be pollinated by abiotic (wind, water) or biotic vectors (bees, flies or birds) which are attracted mainly to nectar or, sometimes, to oil (Kampny 1995; Stevens 2001; Albach et al. 2005).

Oil as reward is almost restricted to the neotropical Angelonieae tribe (Tab. 1), which comprises four genera with oil flowers (Angelonia, Basistemon, Monopera and Monttea) and two genera that lack that reward (Melosperma and Ourisia) (see Martins \& Alves-dos-Santos 2013; Martins et al. 2014). The flowers of the Monttea species also have nectarsecreting tissue at the base of the ovary (Sérsic \& Cocucci 1999), sometimes with no detectable nectar (Simpson et al. 1990; Tadey 2011). In addition, oil-producing flowers are also recorded in one Gratioleae species, Mecardonia tenella, but no information is available regarding interaction with oil-collecting bees (Cappellari et al. 2009, Tab. 1).

In contrast with the findings of Renner \& Schaefer (2010) that point out one independent origin of oil flowers in Plantaginaceae, Martins et al. (2014) found that the oil-producing condition evolved four or five times within the Angelonieae.

Martins \& Alves-dos-Santos (2013) present a consistent review containing information on geographical distribution, flower morphology and oil-collecting bees of oil-producing Angelonieae species. In general, the oil flowers are purple or white, gamopetalous and have a set of oil-secreting trichomes located on the inner side of one (Monopera) or two (Angelonia, Monttea and Basistemon) more-or-less defined corolla sacs (see Martins \& Alves-dos-Santos 2013).

Vogel (1974) provided the first record of the morphology of the secretory trichomes in Angelonia species, especially in A. angustifolia (Tab. 2). After this, some superficial information has appeared in the work of Simpson et al. (1990), Vogel \& Machado (1991) and Sérsic \& Cocucci (1999) (Tab. 2). In general the secretory trichomes are constituted by a multicellular stalk and a digitate or capitate multicellular head. They vary in relation to the morphology, head and stalk cell number, positioning and density.

Information on subcellular features of these secretory trichomes could not be found.

Based on thin-layer chromatography, Vogel \&Machado (1991) concluded that the oil from four Angelonia species consists of mono and/or diglycerides of monohydroxy fatty acids similar to that observed by Vogel (1974).

Centridini (Centris) bees are the main visitors observed in most of the oil flowers of the Plantaginaceae species, but Tapinotaspidini (Arhysoceble, Caenomanda, Chalepogenus, Lophopedia, Paratetrapedia, Tapinotaspis) and Tetrapediini (Tetrapedia) bees have also been recorded (Vogel 1974; Simpson et al. 1990; Vogel \& Machado 
1991; Sérsic \& Cocucci 1999; Machado et al. 2002; Tadey 2011; Martins et al. 2013; Ferreiro et al. 2015). In general, the bees land on the flowers and insert their front legs into the floral sacs simultaneously to gather the oil, meanwhile they contact the reproductive parts, generally with their heads or with the dorsal surfaces of their thoraxes (Vogel 1974; Simpson et al. 1990; Vogel \& Machado 1991; Machado et al. 2002; Martins et al. 2013).

\section{Scrophulariaceae}

The Scrophulariaceae sensu stricto is a family with approximately 59 genera and 1880 species, which occur predominantly in the southern hemisphere, particularly in Africa (Olmstead et al. 2001; Stevens 2001). Bees, butterflies, hawkmoths, moths and birds can pollinate the flowers that offer nectar, pollen and sometimes oil as reward (Kampny 1995; Fischer 2004).

In this family, oil flowers are restricted to the small Hemimeridae tribe ( $\approx 170 \mathrm{spp}$.), which is constituted by one South American or South African (Alonsoa) and five exclusively African genera (Colpias, Diascia, Diclis, Hemimeris, Nemesia) (Steiner 1996; Olmstead et al. 2001; Oxelman et al. 2005; Tank et al. 2006). Renner \& Schaefer (2010) indicated four independent origins of the oil flowers in the African Scrophulariaceae.

Flowers of some African species of Alonsoa, Colpias, Diascia and Hemimeris have oil-secreting trichomes inside and/or around the entrances of the shallow or deep sacs or spurs located at the lower or upper side of the corolla generally at the base of the lateral lobes (Vogel 1974; 1984; Steiner 1989; 1990; 1996; 1999; 2009; Simpson et al. 1990; Kampny 1995; Olmstead et al. 2001; Steiner \& Whitehead 2002; Fischer 2004; Pauw 2005; Dumri et al. 2008; Tabs. 1, 2).

Diascia barbera was the first Scrophulariaceae s.s. species studied by Vogel (1974). Thereafter, elaiophores have been described, at least superficially, in some species of Alonsoa (Steiner 1989) Colpias (Steiner \& Whitehead 2002), Hemimeris (Pauw 2005) and in other species of Diascia (Vogel 1974; 1984). There is some diversity in the density, number and distribution of the trichomes. In general, the multicellular trichomes are short-stalked (1-2 cells) and have a spherical secretory head covered by a cuticle. The secretory head may present two or three cells in Alonsoa unilabiata (Steiner 1989) to several cells in Hemimeris, Colpias and Diascia species (Vogel 1974; 1984; Steiner \& Whitehead 2002; Pauw 2005).

Some reports indicate the release of droplets of the secretion through the cuticle or the release of the oil only after cuticle rupture (Vogel 1974; 1984; Steiner \& Whitehead 2002). In addition to this, there is no detailed information on the secretory processes, nor on the ultrastructural aspects of the secretory cells.

Information on the chemical composition of the floral oils is provided by Dumri et al. (2008) for six Diascia species.
According to these authors, partially acetylated acylglycerols of (3R)-acetoxy fatty acids are the most common compounds.

Several Diascia species have translucent, UV-absorbing, yellow-dotted depressions at the base of the upper corolla lobe termed "windows", which show great morphological diversity among species (see Steiner 1990; Kampny 1995). Steiner (1990) described this variation in the windows of several Diascia and suggested their function in terms of the orientation of the pollinators.

In 1984, Vogel assumed that the oil-collecting Rediviva bees were the effective pollinators of the Diascia species. After that, other authors have reported female bees of this genus as the main visitors to Alonsoa (Steiner 1989; Kuhlmann \& Hollens 2015), Colpias (Steiner \& Whitehead 2002; Kuhlmann \& Hollens 2015), Hemimeris (Steiner 1989; Pauw 2005; Kuhlmann \& Hollens 2015), besides several other Diascia species (Vogel 1984; Steiner 1989; 1990; 2009; Steiner \& Whitehead 1990; 1991; Whitehead \& Steiner 1992; Whitehead et al. 2008; Kuhlmann \& Hollens 2015) (see Tab. 1). In general, these bees place their heads at the base of the upper corolla lobe ("window") and at the same time introduce both their front legs, which have specially modified setae, into the sacs or spurs to collect oil from the elaiophores. The pollen grains are generally deposited on the ventral surface of the bee's body (sternotribic pollination) (Vogel 1984; Steiner 1989; 1990; 2009; Pauw 2005), but also on the dorsal surface of the body (nototribic pollination), on the head or thorax (Steiner \& Whitehead 2002).

Some researchers observed that there is species-specific variation in the length of the front legs of the Rediviva bees and the spurs of the Diascia flowers, suggesting co-evolution between these groups (Vogel 1984; Steiner \& Whitehead 1990; 1991). In addition, according to Kuhlmann \& Hollens (2015) there is a relation between the type of tarsal pilosity and the availability of floral oil and elaiophore morphology, also suggesting a convergent evolution.

\section{Stilbaceae}

The Stilbaceae is a small family with 11 genera and 39 species which occurs primarily in South Africa (Stevens 2001). Its current circumscription is the result of several studies that have included taxa previously placed in other families (see Rourke 2000; Olmstead et al. 2001, Oxelman et al. 2005). There are few reports on the pollination biology of this family but it is known that Retzia species are bird pollinated and some species from Anastrabe, Bowkeria and Ixianthus are bee pollinated (Steiner 1993; Kampny 1995; Linder 2004). The floral rewards are pollen, nectar and/or oil (Steiner 1993; Kampny 1995; Linder 2004).

According to Renner \& Schaefer (2010), the oil flowers have arisen only once in this family. Oil-secretion is known in Anastrabe (Whitehead \& Steiner 1992), Bowkeria (Vogel 1974; Steiner \& Whitehead 1990; 1991; Whitehead \& Steiner 1992) and Ixianthus (Steiner 1993; Steiner \& 
Whitehead 1996), all belonging to the Bowkerieae tribe that was previously place in the Scrophulariaceae (see Barringer 1993; Oxelman et al. 2005; Tank et al. 2006; Tab.1). According Barringer (1993) the flowers of these genera have a campanulate to funnelform corolla with a conspicuous sac or pouch in the distal half of the tube.

The first and only record on the elaiophore morphology in this family was made by Vogel (1974) in Bowkeria verticillata (Tab. 2). According to him, the trichomal elaiophore occurs on the lower inner surface of the corolla sac. The multicellular trichomes are formed by a head with 18-22 cells and a onetwo celled stalk. The secretions accumulate under the cuticle, but there is no information about their release.

Information on subcellular features and the chemical nature of the secretions was not able to be found.

Rediviva bees have been observed collecting oil from the elaiophores of a few species of Anastrabe (Whitehead \& Steiner 1992), Bowkeria (Steiner \& Whitehead 1991; Whitehead \& Steiner 1992) and Ixianthes (Steiner \& Whitehead 1996) (Tab. 1). According to Steiner \& Whitehead (1996) the bees collect the oil with their front and middle legs, while they contact the reproductive parts of the flowers with the dorsal surfaces of their bodies.

\section{Malpighiales}

\section{Malpighiaceae}

The Malpighiaceae comprises 77 genera and 1300 species distributed in tropical and subtropical regions, with clear predominance $(85 \%)$ in the New World (Anderson 1990; Davis \& Anderson 2010). Oil-collecting bees are the main pollinators of the Malpighiaceae flowers, but pollencollecting bees and wasps are also recorded as floral visitors (Anderson 1979).

This family represents the oldest and the most important clade that offers floral oil as a reward (Vogel 1974; Renner \& Schaefer 2010). The oil is secreted by glands located on the abaxial sides of the sepals in most neotropical Malpighiaceae species (Vogel 1974).

The flowers of the New World members are morphologically very uniform and this fact seems to be related to the attraction, orientation and reward of the specific pollinators. (Anderson 1979). In general they are bilaterally symmetrical, have a pair of glands in four or in all five sepals, five free and clawed petals with the posterior one differentiated from the others, ten stamens and a tricarpellate gynoecium (Anderson 1979; Fig. 1D-F). In turn, the flowers of the approximately 150 Old World members can display a diverse array of morphologies, generally lacking the characteristic bilateral symmetry and the sepal glands (Davis \& Anderson 2010). Most of these species have actinomorphic or zygomorphic flowers but in the latter case with two posterior petals (Zhang et al. 2010; Davis et al. 2014).
Many morphological and molecular evidences indicate that this family appeared in the New World (Taylor \& Crepet 1987; Anderson 1979; 1990; Davis et al. 2001; Davis et al. 2002; Davis et al. 2004; Davis \& Anderson 2010) and reach the Old World nine times (Davis \& Anderson 2010). Davis \& Anderson (2010) show that the Old World clades are more closely related to New World ones, than to one another. Based on this and other evidences, several authors have suggested the floral conservatism is result of the stabilizing selection imposed by the specialized oil bees, which are neotropical endemics (Anderson 1979; Davis \& Anderson 2010; Davis et al. 2014).

Despite the large numbers of representatives with oil flowers (Tab. 1) and the importance of the oil in the evolutionary process of this plant group, few species were studied in relation to the morphological and functional aspects of the elaiophores (Tab. 2).

Vogel (1974) was the first to demonstrate that the sepal glands are oil-secreting rather than nectar-secreting as previously believed. In this publication he provided some data on the morphology of the elaiophores of Malpighia glabra, Heteropterys chrysophylla and Stigmaphyllon littorale, among other neotropical species and the paleotropical species Hiptage benghalensis and Acridocarpus smeathmannii he treated more superficially.

The sepal glands are synapomorphic for the family, their absence being considered a derived feature (Vogel 1974; 1990a; Anderson 1979; 1990). They occur in 90 \% of the neotropical species in which they are related with oil secretion (Vogel 1974; 1990a; Anderson 1979; 1990). In contrast, such glands are present in few paleotropical species all belonging to the genera Hiptage, Tristellateia, Rhinopterys and Acridocarpus (Vogel 1990a). In these species, the glands are smaller, intersepalics and seems to be related with extrafloral nectar secretion, the pollen being the only reward to the pollinators (Vogel 1974; 1990a). Nevertheless, there is a report suggesting lipophilic secretions by the sepal glands of a paleotropical species, Hiptage sericea (Subramanian et al. 1990).

In neotropical Malpighiaceae the presence and number of elaiophores per flower can vary among genera, species, populations, individuals or even flowers. These glands are completely absent in all the species of the Coleostachys, Echinopterys, Lasiocarpus, Ptilochaeta and Thryallis (Anderson 1979), but may also be absent in some species of the Banisteriopsis, Galphimia, Heteropterys and Tetrapterys (Buchmann 1987). Most of the Byrsonima species have ten glands per flower but there are species totally eglandular (Anderson 1981; 2001) or with both glandular or eglandular flowers in different individuals (Teixeira \& Machado 2000). In other genera, for example in the Banisteriopsis (Gates 1982) and Peixotoa (Anderson 1982), the species have typically eight glands per flower. Banisteriopsis muricata (Gates 1982; Sazima \& Sazima 1989), Heteropterys aceroides (Sazima \& Sazima 1989) and Pterandra pyroidea (Cappellari 
et al. 2011) have individuals with glandular and eglandular flowers in the same or in different populations. Banisteriopsis variabilis (Possobom 2013) Diplopterys pubipetala (Possobom et al. 2015), Galphimia brasiliensis (Castro et al. 2001), Heteropterys alternifolia (Costa et al. 2006) and Stigmaphyllon paralias (Carvalho et al. 2005; Costa et al. 2006) have different numbers of elaiophores per flower in the same individuals.

Vogel (1990a) hypothesized that the absence or reduction of the number of glands in some species may represent a way of saving energy resources. Carvalho et al. (2005), in turn, verified that there is a compensation in the use of energy resources and not economy, since the production of oil in Stigmaphyllon paralias is similar in flowers with eight or ten glands.

Externally, the sepal glands are morphologically very similar among most species, being oval and sessile or short-stalked (see Vogel 1974; Subramanian et al. 1990; Mamede 1993; Laskowski \& Bautista 1999; Castro et al. 2001; Possobom 2013; Possobom et al. 2015; Araújo \& Meira 2016). Long-stalked elaiophores occur only in Dinemagonum, Dinemandra, Heladena and Henleophytum species (Simpson 1989; Cocucci et al. 1996).

The elaiophores of the neotropical Malpighiaceae species are of the epithelial type, since they are constituted by one layer of secretory palisade-like epithelial cells covered by a generally thick cuticle and subtended by a parenchyma with vascular bundles, which gradually merges with the sepal parenchyma (see Vogel 1974; Lorenzo 1981; Mamede 1993; Laskowski \& Bautista 1999; Castro et al. 2001; Cocucci et al. 1996; Castro et al. 2001; Possobom 2013; Possobom et al. 2015; Araújo \& Meira 2016; Tab. 2, Fig. 2A-D). The paleotropical Hiptage sericea has morphologically similar sepal glands (Subramanian et al. 1990). They vary mainly in relation to the epithelium, which can be flat (see Vogel 1974; Lorenzo 1981; Mamede 1993; Cocucci et al. 1996; Laskowski \& Bautista 1999; Castro et al. 2001; Possobom 2013; Possobom et al. 2015; Fig. 2B, C) or convoluted (Vogel 1974; Subramanian et al. 1990; Possobom 2013; Araújo \& Meira 2016; Fig. 2D). The epithelial cells can be more or less elongated and they can remain or not juxtaposed at maturity (Possobom 2013; Fig. 2B-D). Vogel (1974) postulated that the presence of a convoluted epithelium could increase the secretory surface and consequently the amount of secretion.

Another common feature is the accumulation of the secretion inside the subcuticular space (Fig. 1E-G, 2A) before anthesis and the subsequently release through the rupture of the cuticle (Vogel 1974; Subramanian et al. 1990; Cocucci et al. 1996; Castro et al. 2001; Possobom 2013; Possobom et al. 2015) which can be natural through predetermined regions ("pores") or due to the mechanical action exerted mainly by the visitors.

Ultrastructural aspects of these glands were provided by Castro et al. (2001), Possobom (2013) and Possobom et al. (2015). The epithelial secretory cells generally have conspicuous nuclei, dense cytoplasms with extensive endoplasmic reticula, numerous plastids with lipidic inclusions, mitochondria and lipid droplets (Fig. 2E-I). In addition, the presence of dictyosomes, membranous structures within the vacuole or in the periplasmic spaces and vesicles near or incorporated within the plasma membrane are also common ultrastructural features.

Information on the chemical nature of the secretions can be found in Vogel (1974), Simpson \& Neff (1981), Simpson (1989), Lobreau-Callen (1989), Subramanian et al. (1990), Vinson et al. (1997), Seipold et al. (2004), Reis et al. (2007) and Cappellari et al. (2011). Fatty acids are the main components of the oil, but mono-, di- or triglycerides are also common (Simpson 1989; Vinson et al. 1997; Seipold et al. 2004; Reis et al. 2007; Cappellari et al. 2011). In some neotropical species, the floral oils also contain traces of carbohydrates (Lobreau-Callen 1989; Vinson et al. 1997; Castro et al. 2001; Possobom 2013.) characterizing a mixed secretion, which contains lipophilic and hydrophilic compounds. In the few paleotropical species studied, the secretions of the sepal glands can contain carbohydrates (Vogel 1974; Lobreau-Callen 1989) and also fatty acids, sitosterols and triglycerides (triolein) (Subramanian et al. 1990).

In their study on the chemical nature of the Malpighia coccigera, Seipold et al. (2004) hypothesized the origin of the floral oils from the modification of the route or of the enzymes involved in the biosynthesis of epicuticular waxes. According to these authors, such modifications could have produced substances suited to transfer through the plasma membrane and cell wall, but which would likely be deposited under the cuticle. They thus infer that convergence in the evolution of oil-producing flowers in several families may have been driven not only by pollinators but also by biochemical factors.

Centridini (Centris, Epicharis) bees are the most frequent oil-collecting visitors of the neotropical Malpighiaceae species, but Tetrapediini (Tetrapedia) and Tapinotaspidini (Monoeca, Paratetrapedia) are also very common (Vogel 1974; Steiner 1985a; Sazima \& Sazima 1989; Simpson 1989; Barros 1992; Teixeira \& Machado 2000; Sigrist \& Sazima 2004; Carvalho et al. 2005; Benezar \& Pessoni 2006; Costa et al. 2006; Oliveira et al. 2007; Vilhena \& Augusto 2007; Ribeiro et al. 2008; Bezerra et al. 2009; Dunley et al. 2009; Amorim \& Marco 2011; Mendes et al. 2011; Possobom 2013; Sazan et al. 2013; Possobom et al. 2015).

In general, the effective pollinators of the neotropical species often hold the claw of the posterior petal with their mandibles and insert their front and middle legs between the petal claws to reach and gather oil from the glands on the sepals. In this way, they contact the floral reproductive organs with the ventral surfaces of their bodies. After collection, the oil is stored on the hind legs. Some Paratetrapedia and Tetrapedia species are referred as 'oil robbers' and not as effective pollinators, since they generally land directly on the calyx for oil collection (Barros 1992; 

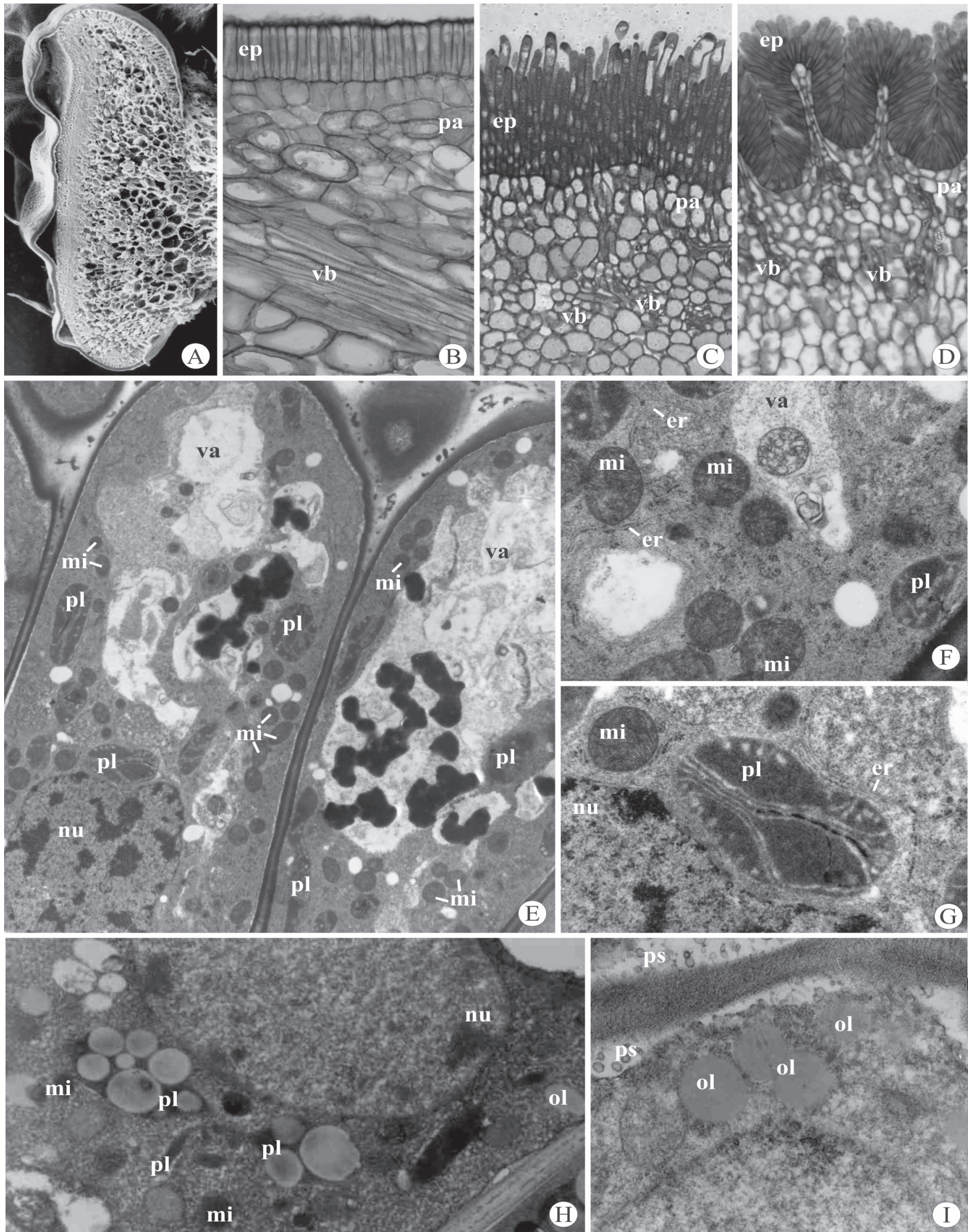

Figure 2. Structural and ultrastructural aspects of the epithelial elaiophores in Malpighiaceae species. A, H, I. Byrsonima intermedia. B, E, F, G. Diplopterys pubipetala. C. Peixotoa reticulata. D. Banisteriopsis variabilis. A. Scanning electron micrograph showing a longitudinal section. Note the wide subcuticular space. B-D. Light micrographs showing the structure of the elaiophores. Note central nuclei (nu), dense cytoplasm with ribossomes, vacuoles with variable content (va), plastids (pl), mitochondria (mi), endoplasmic reticulum (er), oil drops (ol) and periplasmic space (ps). 
Teixeira \& Machado 2000; Sigrist \& Sazima 2004; Vilhena \& Augusto 2007; Mendes et al. 2011; Possobom 2013).

In our previous studies, we suggest there are, in addition to the morphological cues, other features that can be related to the attraction and orientation of pollinators (Possobom 2013; Possobom et al. 2015). In some Malpighiaceae species, we studied the small glands located on the petal margins, mainly on the basal portion. These glands were interpreted by us as osmophores and their location near the petal claws indicate they can play an important role in bee attraction and also in precise positioning for collecting oil from the elaiophores. Despite this record, there is no experimental information showing how the bees are attracted to Malpighiaceae oil flowers.

Reis et al. (2007) isolated two new fatty acid derivatives (Tetrapedic acids A and B) from the nest of Tetrapedia diversipes bees and a new fatty acid derivative from the floral oil of Byrsonima intermedia (Byrsonic acid) which resembles the Oncidinol found in the floral oil of several Oncidiinae species (Orchidaceae). As these compounds (Byrsonic acid, Oncidinol, Tetrapedic acids) share similar chemical structures, the authors suggest the bees manipulate the floral oil collected from either Malpighiaceae or Orchidaceae species and, further, that the Tetrapedic acids ( $A$ and $B$ ) may be products of biotransformation by hydrolases secreted by the female's mandibles. Thus, these authors expand our understanding of how oil-collecting bees use floral oils and they also raise the possibility of chemical mimicry between some Malpighiaceae and Orchidaceae species, in addition to the well known morphological similarities.

\section{Solanales}

\section{Solanaceae}

The Solanaceae is a cosmopolitan family that includes 102 genera and 2460 species (Stevens 2001). They exhibit great diversity in terms of floral morphology and pollinator syndromes (see Knapp 2010). Their pollinators include bats, bees, butterflies, hummingbirds and moths, which forage for pollen, nectar and sometimes for oil (see Knapp 2010).

Oil flowers occurs in most of the species of Nierembergia (Tab. 1), for which this feature is considered a synapomorphy (Tate et al. 2009). Simpson \& Neff (1981) provide the first report of oil production in Nierembergia gracilis. Cocucci (1991) carried out morphological and chemical analyses with several species of the Nierembergia, including observations on pollinator behavior.

In general, the Nierembergia species have a set of trichomal elaiophores located inside the corolla tube, forming a ring on the surface of the limb and/or on the base of the filaments (Simpson \& Neff 1981; Cocucci 1991). These oil-secreting trichomes are multicellular and they are constituted by a stalk with $1-2$ cells ( 4 cells on the filaments) and a wider head with one cell apically compressed (Cocucci
1991). The oil accumulates under the cuticle and after its release by cuticle rupture it remains between the hairs and the papillose epithelial cells of the corolla limb (Cocucci 1991).

In this family, we could not find information on the subcellular characteristics of the elaiophores.

According to Simpson \& Neff (1981) the oil from Nierembergia flowers is constituted mainly by $\beta$-acetoxy fatty acids but also other types of lipids and phenolic compounds.

The oil can be collected with the front or the middle legs by the oil-colleting bees of Centridini (Centris) and Tapinotaspidini (Chalepogenus, Lanthanomelissa, Paratetrapedia, Tapinotaspis) (Cocucci 1991; Cosacov et al. 2008; Nattero et al. 2010). Most of these bees touch the fertile parts while collecting oils and the pollination may be nototribic or sternotribic (Cocucci 1991).

\section{Zygophyllales}

\section{Krawmeriaceae}

Krameria is the only genus of this family and its 18 species can occur in warm arid and semiarid areas of America, with one of them in the West Indies (Simpson \& Saliwon 1999; Stevens 2001; Simpson et al. 2004; Simpson 2007).

The Krameria flowers are zygomorphic and consist generally of five conspicuous and colored sepals and five reduced petals, the lower two modified into scale-like glands, one on either side of the ovary (Simpson \& Saliwon 1999; Simpson et al. 2004; Simpson 2007). Since 1758, such glands have been described as nectaries (see Simpson 1982). In 1974, Vogel predicted that these structures were elaiophores.

According to Renner \& Schaefer (2010), the oilproducing condition has arisen only once in Krameriaceae and apparently it is also the only family which did not lose this condition in any lineage. According to Simpson et al. (2004) there are two major clades within Krameriaceae, one with rugose elaiophores and the other with elaiophores restricted to the distal portion or with striate secretory surfaces.

Morphological aspects of the elaiophores from Krameria species were reported by Vogel (1974) and Simpson (1982). In general they are constituted by one layer of more or less elongated epithelial cells covered by a cuticle and a subtending parenchyma (Vogel 1974; Simpson 1982). The secretory epithelium may occupy the entire surface or only the distal portion of the modified petals and it may be flat or undulate depending on the species (Simpson 1982). The secretions accumulate under the cuticle and may be released by pores (Vogel 1974) or after cuticle rupture by an oil-collecting bee (Simpson et al. 1977; Simpson \& Neff 1981; Simpson 1982).

Some ultrastructural features of the secretory cells are provided by Simpson and Johnson (see Simpson \& Neff 
1981). According to these authors the cells have a dense cytoplasm and contain abundant leucoplasts, endoplasmatic reticulum with formation of vesicles and lipid droplets. They did not observe large lipid accumulations within the cell, concluding that the oil is transported as soon as it is synthesized.

The chemical nature of the oil was investigated in some Krameria species by Simpson and collaborators (Simpson et al. 1977; 1979; Seigler et al. 1978; Simpson \& Neff 1981). According to these authors, the oil is constituted mainly by $\beta$-acetate substituted free fatty acids.

Centris bees are considered the most frequent visitors of Krameria flowers (Simpson et al 1977; Simpson \& Neff 1981; Gimenes \& Lobão 2006; Carneiro et al. 2015; Tab. 1). Female bees collect the oil from the elaiophores with their pairs of front and middle legs and after they transfer it to their hind legs (Simpson et al 1977; Simpson \& Neff 1981; Gimenes \& Lobão 2006; Carneiro et al. 2015). While collecting the oil, these bees often contact the reproductive structures, being considered effective pollinators (Simpson et al 1977; Gimenes \& Lobão 2006; Carneiro et al. 2015).

\section{Considerations}

The classification of a secretory structure as an elaiophore depends on an integrated analysis involving morphological, chemical (or histochemical) and ecological aspects. The analysis of only one of these criteria can create an inaccurate, over or underestimate of occurrence.

So far, elaiophores are reported in approximately 100 plant genera, belonging to 11 families and seven orders (Tab. 1). Together, these genera total about 3000 species but it is likely only a little more than half of them actually really bear elaiophores. A reliable number for the oil-producing species remains difficult to establish, since morphological, chemical and ecological data are scarce and often imprecise, especially for the species-rich families such as the Orchidaceae. Moreover, for many of these families, accurate taxonomic identification and sufficient phylogenetic knowledge are lacking.

Most of the oil-producing plants occur in the tropics and subtropics of South America (Calceolariaceae, Iridaceae, Krameriaceae, Malpighiaceae, Orchidaceae, Plantaginaceae and Solanaceae) and Africa (Cucurbitaceae, Iridaceae, Orchidaceae, Scrophulariaceae and Stilbaceae), but Lysimachia species (Primulaceae) occur in temperate and subtropical regions of the North Hemisphere.

The oil flowers are mostly zygomorphic, bisexual and nectarless, but they are actinomorphic in most of the Cucurbitaceae, Iridaceae, Primulaceae and Solanaceae species. Flowers that offer both nectar and oil occur in $T$. parviflora (Iridaceae), Monttea (Plantaginaceae) and in the Cucurbitaceae species. Only Cucurbitaceae has unisexual flowers. The oil-secreting structures can be located either on the dorsal portions of the flowers, outside of the sepals (as in the Malpighiaceae species) or on the ventral portions, on the inner protective whorls or on the androecium (Tab.2).

With the exception of Krameriaceae and Malpighiaceae, trichomal elaiophores occur in all other plant families. Trichomal elaiophores predominate in the Iridaceae family, but one species $T$. parviflora has the epithelial type. Epithelial, trichomal and intermediate elaiophores are reported for Orchidaceae species, which are the most diverse in relation to the location and morphology of such secretory structures. All other families have exclusively one type of elaiophore (Tab.2).

Detailed morphological descriptions of the elaiophores and ultrastructural studies are lacking for several families. In general, the epithelial elaiophores are very similar among the taxa, being often constituted by more or less elongated epithelial cells, a subepithelial parenchyma and a subtending and vascularized parenchyma. The oil-secreting trichomes are grouped in a more or less dense arrangements and can be unicellular in the monocot members or multicellular in the remaining species (Tab. 2). These trichomes are mostly capitate and also morphologically very similar among taxa. Regardless of whether the elaiophores are trichomal or epithelial the ultrastructural features of the secretory cells are very similar among the species studied so far. These cells have typical cellular machinery of glands with lipophilic secretions and seem to share similar paths of synthesis, and manners of accumulation and secretion release.

Data on chemical composition are restricted to a few species and are lacking for some families. Although the floral oils seem to be very similar among the families, the extension of the study of their chemical nature to a greater number of species could indicate more differences among taxa and improve our understanding of the interactions between the host plants and the bees.

There is scant information on the pollination ecology of most plant species with oil-producing flowers. In general, the neotropical plant species are related with the Centridini, Tapinotaspidini and Tetrapediini bees, while the African species are related with Rediviva (Melittidae) or, in the case of Cucurbitaceae, with Ctenoplectra (Ctenoplectrini) bees. The oils from Primulaceae are collected only by the Macropis (Melittidae) bees. These oil-collecting bees may or may not act as effective pollinators, with both sternotribic or nototribic pollen deposition, apparently depending on the plant taxa visited. The conservative morphology of the Malpighiaceae flowers always allows pollen deposition on the ventral surfaces of the bodies of the pollinators, but in other families the floral morphology and elaiophore location can vary even in the same genus, for example in the Iridaceae, Orchidaceae and Calceolariaceae.

There are very specific plant-bee interactions as the case of Diascia plants and some Rediviva bees, but there are also generalist interactions. Some oil-collecting bee species, for example, can collect floral oils from flowers that are very different morphologically. Although some authors point out some morphological and chemical cues, in general there is little information on how bees are attracted and orientated. 
In conclusion we are agreed that additional morphological, chemical and ecological information is needed to obtain a better understanding of the evolution of this specialized pollination system.

\section{Acknowledgements}

The authors thank to the Fundação de Amparo à Pesquisa do Estado de São Paulo (FAPESP BIOTA-08/55434-7, IC 03/04207-7, MS 06/54268-0 and DR-08/57650-9) and the Conselho Nacional de Pesquisa e Desenvolvimento Tecnológico (CNPq- PQ/Proc.304396/2015-0) for grants to S.R. Machado. We would like to thank Sergio Akira Adachi for kindly providing us his photographs of the Orchidaceae species, the technicians of the Electron Microscopy Center (CME) of IBB UNESP for the lab assistance and the two anonymous reviewers for the valuable comments.

\section{References}

Aguiar AJC, Melo GAR. 2009. Notes on oil sources for the bee genus Caenonomada (Hymenoptera, Apidae, Tapinotaspidini). Revista Brasileira de Entomologia 53: 154-156.

Albach DC, Meudt HM, Oxelman B. 2005. Piecing together the "new" Plantaginaceae. American Journal of Botany 92: 297-315.

Aliscioni SS, Torretta JP, Bello ME, Galati BG. 2009. Elaiophores in Gomesa bifolia (Sims) M.W. Chase \& N.H. Williams (Oncidiinae: Cymbidieae: Orchidaceae): structure and oil secretion. Annals of Botany 104: 1141-1149.

Alves-dos-Santos I, Machado IC, Gaglianone MC. 2007. História natural das abelhas coletoras de óleo. Oecologia Brasiliensis 11: 544-557.

Alves-dos-Santos I, Melo GAR, Rozen JG. 2002. Biology and immature stages of the bee tribe Tetrapediini (Hymenoptera: Apidae). American Museum Novitates 3377: 1-45.

Amorim ME, Marco P. 2011. Polinização de Byrsonima coccolobifolia: isolamento de curta distância e as possiveis causas para baixa produção de frutos. Brazilian Journal of Biology 71: 709-717.

Anderberg AA. 2004. Primulaceae. In: Kubitzki K. (ed.) The families and genera of vascular plants, VI. Berlin Heidelberg, Springer-Verlag. p. 313-319.

Anderberg AA, Manns U, Källerjö M. 2007. Phylogeny and floral evolution of the Lysimachieae (Ericales, Myrsinaceae): Evidence from ndhF sequence data. Willdenowia 37: 407-421.

Anderson C. 1982. A monograph of the genus Peixotoa (Malpighiaceae). Contributions from the University of Michigan Herbarium 15: 1-92.

Anderson WR. 1979. Floral conservatism in Neotropical Malpighiaceae. Biotropica 11: 219-223.

Anderson WR.1981. Malpighiaceae. Memoirs of the New York Botanical Garden 32: 21-305.

Anderson WR. 1990. The origin of the Malpighiaceae - The evidence from morphology. Memoirs of the New York Botanical Garden 64: 210-224.

Anderson WR. 2001. Malpighiaceae. In: Berry PE, Yatskievych K, Holst BK. (eds.) Flora of the Venezuelan Guyana Vol. 6. Saint Louis, Missouri Botanical Garden Press. p. 82-185.

Andersson S. 2006. On the phylogeny of the genus Calceolaria (Calceolariaceae) as inferred from ITS and plastid matK sequences. Taxon. 55: 125-137.

APG - Angiosperm Phylogeny Group IV. 2016. An update of the Angiosperm Phylogeny Group classification for the orders and families of flowering plants: APG IV. Botanical Journal of the Linnean Society 181: 1-20.

Araújo JS, Meira RMSA. 2016. Comparative anatomy of calyx and foliar glands of Banisteriopsis C. B. Rob. (Malpighiaceae). Acta Botanica Brasilica 30: 112-123.
Barringer K.1993. Five New Tribes in the Scrophulariaceae. Novon 3: 15-17. Barros MAG. 1992. Fenologia da floração, estratégias reprodutivas e polinização de espécies simpátricas do gênero Byrsonima Rich (Malpighiaceae). Revista Brasileira de Biologia 52: 343-353.

Benezar RMC, Pessoni LA. 2006. Biologia floral e sistema reprodutivo de Byrsonima coccolobifolia (Kunth) em uma savana amazônica. Acta Amazônica 36: 159-168.

Bezerra ES, Lopes AV, Machado IC. 2009. Biologia reprodutiva de Byrsonima gardnerana A. Juss. (Malpighiaceae) e interações com abelhas Centris no nordeste do Brasil. Revista Brasileira de Botânica 32: 95-108.

Blanco MA, Davies KL, Stpiczyńska M, Carlsward BS, Ionta GM, Gerlach G. 2013. Floral elaiophores in Lockhartia Hook. (Orchidaceae: Oncidiinae): their distribution, diversity and anatomy. Annals of Botany 112: 1775-1791.

Buchmann SL. 1987. The ecology of oil flowers and their bees. Annual Review of Ecology and Systematics 18: 343-369.

Buchmann SL, Buchmann MD. 1981. Anthecology of Mouriri myrtilloides (Melastomataceae: Memecyleae), an oil flower in Panama. Reproductive Botany 1: 7-24.

Cane JH, Eickwort GC, Wesley FR, Spielholz J. 1983. Foraging, grooming and mate-seeking behaviors of Macropis nuda (Hymenoptera, Melittidae) and use of Lysimachia ciliata (Primulaceae) oils in larval provisions and cell linings. American Midland Naturalist 110: 257-264.

Cappellari SC, Haleem MA, Marsaioli AJ, Tidon R, Simpson BB. 2011. Pterandra pyroidea: a case of pollination shift within Neotropical Malpighiaceae. Annals of Botany 107: 1323-1334.

Cappellari SC, Harter-Marques B, Aumeier P, Engels W. 2009. Mecardonia tenella (Plantaginaceae) attracts oil-, perfume-, and pollen-gathering bees in Southern Brazil. Biotropica 41: 721-729.

Carneiro LT, Aguiar AJC, Martins CF, Machado IC, Alves-dos-Santos, I. 2015 Krameria tomentosa oil flowers and their pollinators: bees specialized on trichome elaiophores exploit its epithelial oil glands. Flora 215: 1-8.

Carvalho PD, Borba EL, Lucchese AM. 2005. Variação no número de glândulas e produção de óleo em flores de Stigmaphyllon paralias A. Juss. (Malpighiaceae). Acta Botanica Brasilica 19: 209-214.

Castro MA, Vega AS, Múlgura ME. 2001. Structure and ultrastructure of leaf and calyx glands in Galphimia brasiliensis (Malpighiaceae). American Journal of Botany 88: 1935-1944.

Chase MW, Cameron KM, Freudenstein JV, Pridgeon AC, Salazar G, Berg C, Schuiteman A. 2015. An updated classification of Orchidaceae. Botanical Journal of the Linnean Society 177: 151-174.

Chauveau O, Eggers L, Raquin C, et al. 2011. Evolution of oil-producing trichomes in Sisyrinchium (Iridaceae): insights from the first comprehensive phylogenetic analysis of the genus. Annals of Botany 107: 1287-1312.

Chauveau O, Eggers L, Souza-Chies TT, Nadot S. 2012. Oil-producing flowers within the Iridoideae (Iridaceae): evolutionary trends in the flowers of the New World genera. Annals of Botany 110: 713-729.

Cocucci AA. 1991. Pollination biology of Nierembergia (Solanaceae). Plant Systematics and Evolution 174: 17-35.

Cocucci AA, Holgado AM, Anton AM. 1996. Estudio morfológico y anatómico de los eleóforos pedicelados de Dinemandra ericoides, Malpighiácea endémica del desierto de Atacama, Chile. Darwiniana 34:183-192.

Cocucci AA, Sérsic A, Roig-Alsina A. 2000. Oil-collecting structures in Tapinotaspidini: their diversity, function and probable origin. Mitteilungen der Munchner Entomologischen Gesellschaft 90: 51-74.

Cocucci AA, Vogel S. 2001. Oil producing flowers of Sisyrinchium species (Iridaceae) and their pollinators in southern South America. Flora 196: 26-46.

Cosacov A, Cocucci AA, Sérsic AN. 2012. Variación geográfica de la recompensa floral de Calceolaria polyrhiza (Calceolariaceae): Influencia de factores bióticos y abióticos. Boletín de la Sociedad Argentina de Botánica 47: 363-373.

Cosacov A, Cocucci AA, Sérsic AN. 2014. Geographical differentiation in floral traits across the distribution range of the Patagonian oilsecreting Calceolaria polyrhiza: do pollinators matter? Annals of Botany 113: 251-266.

Cosacov A, Nattero J, Cocucci AA. 2008. Variation of pollinator assemblages and pollen limitation in a locally specialized system: the oil-producing Nierembergia linariifolia (Solanaceae). Annals of Botany 102: 723-734. 
Cosacov A, Sérsic AN, Sosa V, De-Nova A, Nylinder S, Cocucci AA. 2009. New insights into the phylogenetic relationships, character evolution, and phytogeographic patterns of Calceolaria (Calceolariaceae). American Journal of Botany 96: 2240-2255.

Costa CBN, Costa JAS, Ramalho M. 2006. Biologia reprodutiva de espécies simpátricas de Malpighiaceae em dunas costeiras da Bahia, Brasil. Revista Brasileira de Botânica 29: 103-114.

Davies KL, Stpiczyńska M. 2009. Comparative histology of floral elaiophores in the orchids Rudolfiella picta (Schltr.) Hoehne (Maxillariinae sensu lato) and Oncidium ornithorhynchum H.B.K. (Oncidiinae sensu lato). Annals of Botany 104: 221-234.

Davies KL, Stpiczyńska M, Rawski M. 2014. Comparative anatomy of floral elaiophores in Vitekorchis Romowicz \& Szlach., Cyrtochilum Kunth and a florally dimorphic species of Oncidium Sw. (Orchidaceae: Oncidiinae). Annals of Botany 113: 1155-1173.

Davis CC, Anderson WR. 2010. A complete generic phylogeny of Malpighiaceae inferred from nucleotide sequence data and morphology. American Journal of Botany 97: 2031-2048.

Davis CC, Anderson WR, Donoghue MJ. 2001. Phylogeny of Malpighiaceae: evidence from chloroplast NDHF and TRNL-F nucleotide sequences. American Journal of Botany 88: 1830-1846.

Davis CC, Bell CD, Mathews S, Donoghue MJ. 2002. Laurasian migration explains gondwanan disjunctions: evidence from Malpighiaceae. Evolution 99: 6833-6837.

Davis CC, Fritsch PW, Bell CD, Mathews S. 2004. High-latitude tertiary migrations of an exclusively tropical clade: evidence from Malpighiaceae. International Journal of Plant Sciences 165: 107-121.

Davis CC, Schaefer H, Xi Z, Baum DA, Donoghue MJ, Harmone LJ. 2014. Long-term morphological stasis maintained by a plant-pollinator mutualism. Proceedings of the National Academy of Sciences 111: 5914-5919.

Dötterl S, Schäffler I. 2007. Flower scent of floral oil-producing Lysimachia punctata as attractant for the oil bee Macropis fulvipes. Journal of Chemical Ecology 33: 441-445

Dumri K, Seipold L, Schmidt J, et al. 2008. Non-volatile floral oils of Diascia spp. (Scrophulariaceae). Phytochemistry 69: 1372-1383.

Dunley BS, Freitas L, Galetto L. 2009. Reproduction of Byrsonima sericea (Malpighiaceae) in restinga fragmented habitats in southeastern Brazil. Biotropica 41: 692-699.

Ferreiro G, Baranzelli MC, Sérsic AN, Cocucci AA. 2015. Clinal variability of oil and nectar rewards in Monttea aphylla (Plantaginaceae): relationships with pollinators and climatic factors in the Monte Desert. Botanical Journal of The Linnean Society 178: 314-328.

Fischer E. 2004. Scrophulariaceae. In: Kubitzki K. (ed.) The families and genera of vascular plants, VI. Berlin Heidelberg, Springer-Verlag. p. 333-432.

Gates B. 1982. Banisteriopsis and Diplopterys (Malpighiaceae). Flora Neotropica Monograph 30: 1-237.

Gimenes M, Lobão CS. 2006. A polinização de Krameria bahiana B.B. Simpson (Krameriaceae) por abelhas (Apidae) na Restinga, BA. Neotropical Entomology 35: 440-445.

Goldblatt P, Manning JC. 2006. Radiation of Pollination Systems in the Iridaceae of sub-Saharan Africa. Annals of Botany 97: 317-344.

Goldblatt P, Manning JC, Rudall P. 1998. Iridaceae. In: Kubitzki K. (ed.) The families and genera of vascular plants, III. Berlin Heidelberg, Springer-Verlag. p. 295-333.

Gomiz NE, Torretta JP, Aliscioni SS. 2013. Comparative anatomy of elaiophores and oil secretion in the genus Gomesa (Orchidaceae). Turkish Journal of Botany 37: 859-871.

Gomiz NE, Torretta JP, Aliscioni SS. 2014. Zygostates alleniana (Orchidaceae: Epidendroideae: Cymbidieae: Oncidiinae): estructura floral relacionada con la polinizacion. Anales del Jardin Botanico de Madrid 71: 1-9.

Hao G, Yuan YM, Hu CM, Ge XJ, Zhao NW. 2004. Molecular phylogeny of Lysimachia (Myrsinaceae) based on chloroplast trnL-F and nuclear ribosomal ITS sequences. Molecular Phylogenetics and Evolution 31: 323-339.

Kampny CM. 1995. Pollination and flower diversity in Scrophulariaceae. The Botanical Review 61: 350-366.

Knapp S. 2010. On 'various contrivances': pollination, phylogeny and flower form in the Solanaceae. Philosophical Transactions of the Royal Society B 365: 449-460
Kocyan A, Zhang LB, Schaefer H, Renner SS. 2007. A multi-locus chloroplast phylogeny for the Cucurbitaceae and its implications for character evolution and classification. Molecular Phylogenetics and Evolution 44: 553-577.

Kuhlmann M, Hollens H. 2015. Morphology of oil-collecting pilosity of female Rediviva bees (Hymenoptera: Apoidea: Melittidae) reflects host plant use. Journal of Natural History 49: 561-573.

Laskowski LE, Bautista D. 1999. Caracteristicas anatomicas de la flor del semeruco (Malpighia emarginata DC.). Ernstia 9: 19-36.

Linder HP. 2004. Stilbaceae. In: Kadereit JW. (ed.) The families and genera of vascular plants, VII. Berlin Heidelberg, Springer-Verlag. p. 433-440.

Linder HP, Kurzweil H. 1994. The phylogeny and classification of the Diseae (Orchidoideae: Orchidaceae). Annals of the Missouri Botanical Garden 81: 687-713.

Lobreau-Callen D. 1989. Les Malpighiaceae et leurs pollinisateurs. Coadaptation ou coévolution. Bulletin du Muséum national d'histoire naturelle. Section B, Adansonia 11: 79-94.

Lorenzo E. 1981. Sobre la inflorescencia, morfologia floral y embriologia de Janusia guaranitica (Malpighiaceae). Kurtziana 14: 101-124.

Machado IC. 2004. Oil-Collecting bees and related plants: a review of the studies in the last twenty years and case histories of plants occurring in NE Brazil. In: Freitas BM, Pereira JOP. (eds.) Solitary bees: Conservation, rearing and management for pollination. Fortaleza; Imprensa Universitária. p. 255-280

Machado IC, Vogel S, Lopes AV. 2002. Pollination of Angelonia cornigera Hook. (Scrophulariaceae) by long-legged, oil-collecting bees in NE Brazil. Plant Biology 4: 352-359.

Mamede MCH. 1993. Estudo comparativo de flores casmógamas, cleistógamas e de frutos de Camarea affins St. Hil. (Malpighiaceae). Acta Botanica Brasilica 7: 21-31

Manning J, Goldblatt P. 2002. The pollination of Tritoniopsis parviflora (Iridaceae) by the oil-collecting bee Rediviva gigas (Hymenoptera: Melittidae): the first record of oil-secretion in African Iridaceae. South African Journal of Botany 68: 171-176

Manning JC, Linder HP. 1992. Pollinators and evolution in Disperis (Orchidaceae), or why are there so many species? South African Journal of Science 88: 38-49.

Martins AC, Alves-dos-Santos I. 2013 Floral-oil-producing Plantaginaceae species: Geographical distribution, pollinator rewards and interactions with oil-collecting bees. Biota Neotropica 13: 77-89.

Martins AC, Aguiar AJC, Alves-Dos-Santos I. 2013. Interaction between oil-collecting bees and seven species of Plantaginaceae. Flora 208: 401-411.

Martins AC, Melo GAR, Renner SS. 2014. The corbiculate bees arose from New World oil-collecting bees: implications for the origin of pollen baskets. Molecular Phylogenetics and Evolution 80: 88-94.

Mayr EM, Weber A. 2006. Calceolariaceae: floral development and systematic implications. American Journal of Botany 93: 327-343.

Mendes FN, Rêgo MMC, Albuquerque PMC. 2011. Fenologia e biologia reprodutiva de duas espécies de Byrsonima Rich. (Malpighiaceae) em área de cerrado no nordeste do Brasil. Biota Neotropica 11: 103-115.

Michener CD. 2007 The bees of the world. 2nd. edn. Baltimore, John Hopkins University Press.

Mickeliunas L, Pansarin ER, Sazima M. 2006. Biologia floral, melitofilia e influência de besouros Curculionidae no sucesso reproductivo de Grobya amherstiae Lindl. (Orchidaceae: Cyrtopodiinae). Revista Brasileira de Botânica 29: 251-258.

Molau U. 1988. Scrophulariaceae-part I. Calceolarieae. Flora Neotropica 47: 1-326.

Murúa M, Cisterna J, Rosende B. 2014. Pollination ecology and breeding system of two Calceolaria species in Chile. Chilena de Historia Natural 87: 7.

Nattero J, Cocucci A, Medel R. 2010. Pollinator-mediated selection in a specialized pollination system: matches and mismatches across populations. Journal of Evolutionary Biology 23: 1957-1968.

Neff JL, Simpson BB. 1981. Oil-collecting structures in the Anthoporidae (Hymenoptera): morphology, function and use in systematics. Journal of Kansas Entomological Society 54: 95-123.

Nepi M, Pacini E. 1994. Nectary structure and types in several Cucurbitaceae. Giornale Botanico Italiano 128: 233-233.

Neubig KM, Whitten WM, Williams NH, et al. 2012. Generic 
recircumscriptions of Oncidiinae (Orchidaceae: Cymbidieae) based on maximum likelihood analysis of combined DNA datasets. Botanical Journal of the Linnean Society 168: 117-146.

Oliveira MIB, Polido CA, Costa LC, Fava WS. 2007. Sistema reprodutivo e polinização de Byrsonima intermedia A. Juss. (Malpighiaceae) em Mato Grosso do Sul, Brasil. Revista Brasileira de Biociências 5: 756-758.

Olmstead RG, de Pamphilis CW, Wolfe AD, Young ND, Elisens WJ, Reeves PA. 2001. Disintegration of the Scrophulariaceae. American Journal of Botany 88: 348-361.

Oxelman B, Kornhall P, Olmstead RG, Bremer B. 2005. Further disintegration of Scrophulariaceae. Taxon 54: 411-425.

Pacek A, Stpiczyńska M. 2007. The structure of elaiophores in Oncidium cheirophorum Rchb.F. and Ornithocephalus kruegeri Rchb.F. (Orchidaceae). Acta Agrobotanica 60: 9-14.

Pacek A, Stpiczyńska M, Davies KL, Szymczak G. 2012. Floral elaiophore structure in four representatives of the Ornithocephalus clade (Orchidaceae: Oncidiinae). Annals of Botany 110: 809-820.

Pansarin ER, Pansarin LM. 2011. Reproductive biology of Trichocentrum pumilum: An orchid pollinated by oil-collecting bees. Plant Biology 13: 576-581.

Pansarin LM, Castro MM, Sazima M. 2009. Osmophore and elaiophores of Grobya amherstiae (Catasetinae, Orchidaceae) and their relation to pollination. Botanical Journal of the Linnean Society 159: 408-415.

Pauw A. 2005. Inversostyly: a new stylar polymorphism in an oil-secreting plant, Hemimeris racemosa (Scrophulariaceae). American Journal of Botany 92: 1878-1886.

Pauw A. 2006. Floral syndromes accurately predict pollination by a specialized oil-collecting bee (Rediviva peringueyi, Melittidae) in a guild of South African orchids (Coryciinae). American Journal of Botany, 93: 917-926.

Possobom CCF. 2013. Estruturas secretoras florais em espécies de Malpighiaceae de cerrado: estrutura, histoquímica e secreção. $\mathrm{PhD}$ Thesis, Universidade Estadual Paulista, São Paulo.

Possobom CCF, Guimarães E, Machado SR. 2015. Structure and secretion mechanisms of floral glands in Diplopterys pubipetala (Malpighiaceae), a neotropical species. Flora 211: 26-39.

Rasmussen C, Olesen JM. 2000. Oil flowers and oil collecting bees. Scandinavian Association for Pollination Ecology honours Knut Faegri 39: 23-31.

Reis MG, Faria AD, Alves-dos-Santos I, Amaral MCE, Marsaioli AJ. 2007. Byrsonic acid - the clue to floral mimicry involving oil-producing flowers and oil-collecting bees. Journal of Chemical Ecology 33: 1421-1429

Reis MG, Faria AD, Amaral MCE, Marsaioli AJ. 2003. Oncidinol - a novel diacylglycerol from Ornithophora radicans Barb. Rodr. (Orchidaceae) floral oil. Tetrahedron. Letters 44: 8519-8523.

Reis MG, Faria AD, Bittrich V, Amaral MCE, Marsaioli AJ. 2000. The chemistry of flower-rewards: Oncidium (Orchidaceae). Journal of the Brazilian Chemical Society 11: 600-608.

Reis MG, Singer RB, Gonçalves R, Marsaioli AJ. 2006. The chemical composition of Phymatidium delicatulum and P. tillandsioides (Orchidaceae) floral oils. Natural Products Communications 1: 757761.

Renner SS, Schaefer H. 2010. The evolution and loss of oil-offering flowers: new insights from dated phylogenies for plants and bees. Philosophical Transactions of the Royal Society B 365: 423-435.

Ribeiro EKMD, Rêgo MMC, Machado ICS. 2008. Pollen loads of pollinator bees of Byrsonima chrysophylla Kunth. (Malpighiaceae): fidelity and alternative sources of flower resources. Acta Botanica Brasilica 22: 165-171.

Rourke JP.2000. A review of generic concepts in the Stilbaceae. Bothalia 30: 9-15.

Rudall PJ, Manning JC, Goldblatt P. 2003. Evolution of floral nectaries in Iridaceae. Annals of the Missouri Botanical Garden 90: 613--631.

Salazar GS, Cabrera LI, Madriñán S, Chase MW. 2009. Phylogenetic relationships of Cranichidinae and Prescottiinae (Orchidaceae, Cranichideae) inferred from plastid and nuclear DNA sequences. Annals of Botany 104: 403-416.

Sazan M, Bezerra ADM, Freitas BM. 2013. Oil collecting bees and Byrsonima cydoniifolia A. Juss. (Malpighiaceae) interactions: the prevalence of long-distance cross pollination driving reproductive success. Anais da Academia Brasileira de Ciências 86: 347-357.

Sazima M, Sazima I. 1989. Oil-gathering bees visit flowers and glandular morphs of the oil-producing Malpighiaceae. Botanica Acta 102: 106111.

Schaefer H, Bartholomew B, Boufford DE. 2012. Indofevillea jiroi (Cucurbitaceae), a new floral oil producing species from Northeastern Myanmar. Harvard Papers in Botany 17: 323-332.

Schaefer H, Renner SS. 2008. A phylogeny of the oil bee tribe Ctenoplectrini (Hymenoptera: Anthophila) based on mitochondrial and nuclear data: Evidence for Early Eocene divergence and repeated out-of-Africa dispersal. Molecular Phylogenetics and Evolution 47: 799-811.

Schaefer H, Renner SS. 2010. A three-genome phylogeny of Momordica (Cucurbitaceae) suggests seven returns from dioecy to monoecy and recent long-distance dispersal to Asia. Molecular Phylogenetics and Evolution 54: 553-560.

Schaefer H, Renner SS. 2011. Phylogenetic relationships in the order Cucurbitales and a new classification of the gourd family (Cucurbitaceae). Taxon 60: 122-138.

Schäffler I, Balao F, Dötterl S. 2012. Floral and vegetative cues in oilsecreting and non-oil-secreting Lysimachia species. Annals of Botany 110: $125-138$.

Schäffler I, Dötterl S. 2011. A day in the life of an oil bee: phenology, nesting, and foraging behavior. Apidologie 42: 409-424.

Schnepf E. 1969. Über den Feinbau von Öldrusen II. Die Drüsenhaare in Calceolaria-Blüten. Protoplasma 67: 195-203.

Seigler DS, Simpson BB, Martin C, Neff JL. 1978. Free 3-acetoxy fatty acids in floral glands of Krameria species. Phytochemistry 17: 995-996.

Seipold L, Gerlach G, Wessjohann L. 2004. A new type of floral oil from Malpighia coccigera (Malpighiaceae) and chemical considerations on the evolution of oil flowers. Chemistry \& Biodiversity 1: 1519-1528.

Sérsic AN, Cocucci AA. 1999. An unusual kind of nectary in the oil flowers of Monttea: its structure and function. Flora 194: 393-404.

Sérsic AN. 2004. Pollination biology in the genus Calceolaria L. (Calceolariaceae). Stapfia 82: 1-122.

Sigrist MR, Sazima M. 2004. Pollination and reproductive biology of twelve species of Neotropical Malpighiaceae: stigma morphology and its implications for the breeding system. Annals of Botany 94: 33-41.

Silvério A, Nadot S, Souza-Chies, TT, Chauveau O. 2012. Floral rewards in the tribe Sisyrinchieae (Iridaceae): oil as an alternative to pollen and nectar? Sexual Plant Reproduction 25: 267-279.

Simpson BB. 1982. Krameria (Krameriaceae) flowers: orientation and elaiophore morphology. Taxon 31: 517-528.

Simpson BB. 1989. Pollination biology and taxonomy of Dinemandra and Dinemagonum (Malpighiaceae). Systematic Botany 14: 408-426.

Simpson BB. 2007. Krameriaceae. In: Kubitzki K. (ed.) The families and genera of vascular plants, IX. Berlin Heidelberg, Springer-Verlag. p. 208-212.

Simpson BB, Neff JL. 1981. Floral rewards: alternatives to pollen and nectar. Annals of Missouri Botanical Garden 68: 301-322.

Simpson BB, Neff JL, Dieringer G. 1990. The production of floral oils by Monttea (Scrophulariaceae) and the function of tarsal pads in Centris bees. Plant Systematics and Evolution 173: 209-222.

Simpson BB, Neff JL, Seigler N. 1977. Krameria, free fatty acids and oilcollecting bees. Nature 267: 150-151.

Simpson BB, Neff JL, Seigler DS. 1983. Floral biology and floral rewards of Lysimachia (Primulaceae). American Midland Naturalist 110: 249-256.

Simpson BB, Salywon A. 1999. Krameriaceae Ratany Family. Journal of the Arizona-Nevada Academy of Science 32: 57-61.

Simpson BB, Seigler DS, Neff JL. 1979. Lipids from the floral glands of Krameria. Biochemical Systematics and Ecology 7: 193-194.

Simpson BB, Weeks A, Helfott DM, Larkin LL. 2004. Species relationships in Krameria (Krameriaceae) based on ITS sequences and morphology: implications for character utility and biogeography. Systematic Botany 29: 97-108.

Singer RB. 2003. Orchid pollination: recent developments from Brazil. Lankesteriana 7: 111-114.

Singer RB, Cocucci AA. 1999. Pollination mechanisms in four sympatric southern Brazilian Epidendroideae orchids. Lindleyana 14: 47-56. 
Ståhl B, Anderberg AA. 2004. Myrsinaceae. In: Kubitzki K. (ed.) The families and genera of vascular plants, VI. Berlin Heidelberg, Springer-Verlag. p. 266-281.

Steiner KE. 1985a. Functional dioecism in the Malpighiaceae: The breeding system of Spachea membranacea Cuatr. American Journal of Botany 72: 1537-1543.

Steiner KE. 1985b. The role of nectar and oil in the pollination of Drymonia serrulata (Gesneriaceae) by Epicharis bees (Anthophoridae) in Panama. Biotropica 17: 217-229.

Steiner KE. 1989. A Second species of the amphi-atlantic genus Alonsoa (Scrophulariaceae) in South Africa. Annals of the Missouri Botanical Garden 76: 1152-1159.

Steiner KE. 1990. The Diascia (Scrophulariaceae) window: an orientation cue for oil-collecting bees. Botanical Journal of the Linnean Society 102: 175-195.

Steiner KE. 1993. Has Ixianthes (Scrophulariaceae) lost its special bee? P1ant Systematics and Evolution 185: 7-16.

Steiner KE. 1996. Chromosome Numbers and Relationships in Tribe Hemimerideae (Scrophulariaceae). Systematic Botany 21: 63-76.

Steiner KE. 1998. The evolution of beetle pollination in a South African orchid. American Journal of Botany 85: 1180-1193.

Steiner KE. 1999. A new species of Diascia (Scrophulariaceae) from the Eastern Cape (South Africa), with notes on other members of the genus in that region. South African Journal of Botany 65: 223-231.

Steiner KE. 2009. Three new species of Diascia (Scrophulariaceae) from the Western Cape, South Africa. Bothalia 39: 11-17.

Steiner KE. 2010. Twin oil sacs facilitate the evolution of a novel type of pollination unit (Meranthium) in a South African orchid. American Journal of Botany 97: 311-323.

Steiner KE, Roman K, Dötterl S. 2011. Strong phylogenetic effects on floral scent variation of oil-secreting orchids in South Africa. American Journal of Botany 98: 1663-1679.

Steiner KE, Whitehead VB. 1990. Pollinator adaptation to oil-secreting flowers - Rediviva and Diascia. Evolution 44: 1701-1707.

Steiner KE, Whitehead VB. 1991. Oil flowers and oil bees: further evidence for pollinator adaptation. Evolution 45: 1493-1501.

Steiner KE, Whitehead VB. 1996.The consequences of specialization for pollination in a rare South African shrub, Ixianthes retziodes (Scrophulariaceae). Plant Systematics and Evolution 201: 131-138.

Steiner KE, Whitehead VB. 2002. Oil secretion and the pollination of Colpias mollis (Scrophulariaceae). Plant systematics and evolution 235: 53-66.

Stevens PF. 2001. Angiosperm Phylogeny Website, Version 12 Jul. 2012. http://www.mobot.org/MOBOT/research/APweb/. 25 Feb. 2017.

Stone RD. 2006. Phylogeny of major lineages in Melastomataceae, subfamily Olisbeoideae: utility of nuclear glyceraldehyde 3-phosphate dehydrogenase (GapC) gene sequences. Systematic Botany 31: 107-121.

Stpiczyńska M, Davies KL. 2008. Elaiophore structure and oil secretion in flowers of Oncidium. Annals of Botany 101: 375-384.

Stpiczyńska M, Davies KL, Gregg A. 2007. Elaiophore diversity in three contrasting members of the Oncidiinae Benth. (Orchidaceae). Botanical Journal of the Linnean Society 155: 135-148.

Stpiczyńska M, Davies KL, Pacek-Bieniek A, Kaminska M. 2013. Comparative anatomy of the floral elaiophore in representatives of the newly re-circumscribed Gomesa and Oncidium clades (Orchidaceae: Oncidiinae). Annals of Botany 112: 839-854.

Subramanian RB, Arumugasamy K, Inamdar JS. 1990. Studies in secretory glands of Hiptage sericea (Malpighiaceae). Nordic Journal of Botany 10: 57-62.

Sung IH, Dubitzky A, Eardley C, Yamane S. 2009. Descriptions and biological notes of Ctenoplectra bees from Southeast Asia and Taiwan (Hymenoptera: Apidae: Ctenoplectrini) with a new species from North Borneo. Entomological Science 12: 324-340.

Tadey M. 2011. Reproductive biology of Monttea aphylla (Scrophulariaceae). Australian Journal of Botany 59: 713-718.

Tank DC, Beardsley PM, Kelchner AS, Olmstead RG. 2006. Review of the systematics of Scrophulariaceae s.l. and their current disposition. Australian Systematic Botany 19: 289-307.

Tate JA, Acosta MC, McDill J, Moscone EA, Simpson BB, Cocucci AA. 2009. Phylogeny and character evolution in Nierembergia (Solanaceae):
Molecular, morphological, and cytogenetic evidence. Systematic Botany 34: 198-206.

Taylor DW, Crepet WL. 1987. Fossil floral evidence of Malpighiaceae and an early plant-pollinator relationship. American Journal of Botany 74: 274-286.

Teixeira LAG, Machado IC. 2000. Sistema de polinização e reprodução de Byrsonima sericea DC. (Malpighiaceae). Acta Botanica Brasilica 14: 347-357.

The Plant List. 2013. Version 1.1. http://www.theplantlist.org/. 09 Jan. 2017.

Torretta JP, Gomiz NE, Aliscioni SS, Bello ME. 2011. Biología reproductiva de Gomesa bifolia (Orchidaceae, Cymbidieae, Oncidiinae). Darwiniana 49: 16-24.

Vilhena AMGF, Augusto SC. 2007. West Indian cherrys Malpighia emarginata DC. (Malpighiaceae) pollinators in savanna area of Triângulo Mineiro. Biosciences Journal of Uberlândia 23: 14-23.

Vinson SB, Frankie GW, Williams HJ. 1996. Chemical ecology of bees of the genus Centris (Hymenoptera: Apidae). The Florida Entomologist 79: 109-129.

Vinson SB, Williams HJ, Frankie GW, Shrum G. 1997. Floral lipid chemistry of Byrsonima crassifolia (Malpighiaceae) and a use of floral lipid by Centris bees (Hymenoptera: Apidae). Biotropica 29: 76-83.

Vogel S, Machado IC. 1991. Pollination of four sympatric species of Angelonia (Scrophulariaceae) by oil-collecting bees in NE Brazil. Plant Systematics and Evolution 178: 153-178.

Vogel S. 1969. Flowers offering fatty oil instead of nectar. In: Proceedings of the XI International Botanical Congress. Seattle. p. 229.

Vogel S. 1971. Ölproduzierende Blumen, die durch ölsammelnde Bienen bestäubt werden. Die Naturwissenschaften 58: 58-58.

Vogel S. 1974. Ölblumen und ölsammelnde Bienen. Tropische und subtropische Pflanzenwelt 7: 283-547.

Vogel S. 1976a. Lysimachia: Olblumen der Holarktis. Naturwissenschaften 63: 44-45.

Vogel S. 1976b. Oil collecting bees of the Old World and their flowers. In: Proceedings of XV International Entomological Congress. Washington.

Vogel S. 1981. Abdominal oil-mopping - a new type of foraging in bees. Naturwissenschaften 68: 627-628.

Vogel S. 1984. The Diascia flower and its bee - an oil-based symbiosis in southern Africa. Acta Botanica Neerlandica 33: 509-518.

Vogel S. 1986. Ölblumen und ölsammelnde Bienen. Zweite Folge: Lysimachia und Macropis. Tropische und subtropische Pflanzenwelt 54: 149-312.

Vogel S. 1988. Die Ölblumensymbiosem - Parallelismus und andere Aspekte ihrer Entwicklung in Raum und Zeitschrift für Zoologische und Systematische Evolutionsforschungen 26: 341-362.

Vogel S. 1990a. History of Malpighiaceae in the light of pollination ecology. Memoirs of the New York Botanical Garden 55: 130-142.

Vogel S. 1990b. Ölblumen und ölsammelnde Bienen. Dritte Folge. Momordica, Thladiantha und die Ctenoplectridae. Tropische und subtropische Pflanzenwelt 73: 1-186.

Vogel S. 2009. The non-African oil flowers and their bees: A brief survey. SAAB Annual Meeting Abstracts. South African Journal of Botany 75: 389-390.

Waterman RJ, Pauw A, Barraclough TJ, Savolainen V. 2009. Pollinators underestimated: A molecular phylogeny reveals widespread floral convergence in oil-secreting orchids (sub-tribe Coryciinae) of the Cape of South Africa. Molecular Phylogenetics and Evolution 51: 100-110.

Whitehead VB, Steiner KE. 1992. Two new species of oil-collecting bees of the genus Rediviva from the summer rainfall region of South Africa (Hymenoptera, Apoidea, Melittidae) Annals of The South African Museum 102: 143-164.

Whitehead VB, Steiner KE. 1993. A new Rediviva bee (Hymenoptera: Apoidea: Melittidae) that collects oil from orchids. African Entomology 1: 159-166.

Whitehead VB, Steiner KE, Eardley CD. 2008. Oil collecting bees mostly of the summer rainfall area of southern Africa (Hymenoptera: Melittidae: Rediviva). Journal of the Kansas Entomological Society 81: 122-141.

Zhang W, Kramer EM, Davis CC. 2010. Floral symmetry genes and the origin and maintenance of zygomorphy in a plant pollinator mutualism. In: Proceedings of the National Academy of Sciences of the United States 107: 6388-6393. 